Article

\title{
Towards a Comprehensive Framework for Climate Change Multi-Risk Assessment in the Mining Industry
}

\author{
Evangelos Mavrommatis ${ }^{1, *(\mathbb{C})}$, Dimitris Damigos ${ }^{1}$ (D) and Sevastianos Mirasgedis ${ }^{2}$ \\ 1 School of Mining and Metallurgical Engineering, National Technical University of Athens, \\ 15780 Athens, Greece \\ 2 Institute for Environmental Research and Sustainable Development, National Observatory of Athens, \\ Lofos Nimfon, Thission, 11810 Athens, Greece \\ * Correspondence: emavro@metal.ntua.gr; Tel.: +30-2107722215; Fax: +30-2107722156
}

Received: 8 May 2019; Accepted: 20 June 2019; Published: 26 June 2019

\begin{abstract}
Changing climate conditions affect mining operations all over the world, but so far, the mining sector has focused primarily on mitigation actions. Nowadays, there exists increasing recognition of the need for planned adaptation actions. To this end, the development of a practical tool for the assessment of climate change-related risks to support the mining community is deemed necessary. In this study, a comprehensive framework is proposed for climate change multi-risk assessment at the local level customized for the needs of the mining industry. The framework estimates the climate change risks in economic terms by modeling the main activities that a mining company performs, in a probabilistic model, using Bayes' theorem. The model permits incorporating inherent uncertainty via fuzzy logic and is implemented in two versatile ways: as a discrete Bayesian network or as a conditional linear Gaussian network. This innovative quantitative methodology produces probabilistic outcomes in monetary values estimated either as percentage of annual loss revenue or net loss/gains value. Finally, the proposed framework is the first multi-risk methodology in the mining context that considers all the relevant hazards caused by climate change extreme weather events, which offers a tool for selecting the most cost-effective action among various adaptation strategies.
\end{abstract}

Keywords: climate change; risk assessment; mining; adaptation; Bayesian networks

\section{Introduction}

According to the Fifth Assessment Report (AR5) of Working Group (WG) I of the Intergovernmental Panel on Climate Change (IPCC), the observed climate changes attributed to human activity could be summarized as snow melting and reduced snow cover, permafrost thaw, air temperature increase, more frequent temperature extremes, droughts increase, frequency increase of intense precipitation, flooding, hurricanes, tornadoes, other extreme weather events, sea level rise, and more frequent wildfires [1]. All these phenomena affect the mining sector in various ways.

Intense downpours seriously affect mine geomorphology and drainage, causing intense stability problems to mine benches, waste disposal areas, and tailing dams; overflow of ponds, dams, reservoirs, ditches, and culverts; loss of machinery and equipment; damages on haul roads and other transportations facilities; productivity loss; operations disruptions; and personnel risk injury [2-12]. On the contrary, reduced precipitation may exacerbate water-use pressures to water-intensive processes [7,13-15]. Temperature rise causes ice road melting, enormously increasing the transportation costs of arctic mines [16,17], whereas permafrost thaw may cause static problems to various mine site infrastructure foundations $[16,18]$. Temperature rise along with precipitation decrease adversely affect 
both hydroelectricity production and mine energy prices [19] and wet tailings facilities, increasing water consumption in perpetuity [20]. Furthermore, extended droughts negatively affect the water withdrawals of mining firms, while plants in rehabilitated areas increase irrigation needs and may cause frequent wildfires destroying past rehabilitations, ore seams, equipment, or assets [19,21]. Extreme winds and precipitation may cause the overtopping of toxic wastes and lead into mine discharges from tailing dams $[10,20]$. Extreme high temperatures negatively affect the mining industry globally by declining productivity and rational decision making and increasing personnel absenteeism and the risk of heat-related illnesses such as malaria $[13,14,19]$. Extreme weather events (typhoons, floods, heat waves) may damage the vegetation cover of tailing dams [20], as well as adversely affect electric power generation and transmission, causing a significant risk to mining companies [19,21]. Sea level rise may affect port facilities causing market and/or supply chain disruptions [13,19,22-25]. Nevertheless, the mining sector may be possibly benefited in some occasions from climate change, e.g., increased ambient temperatures and decreased snowfall in the Arctic or cold climates such as Greenland will allow prospecting, operations, and shipping (i.e., new ice-free channels) throughout the year [13,19,26-29]. Notable climate change-related incidents in the mining industry include: (i) the premature Winter Road closure, in Northwest Territories, Canada, in 2006 that resulted in an extra cost of \$11.25 million to Rio Tinto's Diavik diamond mine and the bankruptcy of the Tahera Diamond Corporation, which operated the Jericho diamond mine [16,30]; (ii) the 2012 floods in Queensland, Australia, that hit 85\% of region's coal mines and created losses of more than 2.5 billion dollars [31] and a significant drop to the country's gross domestic product [32]; (iii) the 2008 flooding incident to Ensham coal mine in Central Queensland, Australia, which provoked direct losses of more than AU \$300 million due to decreased production capacity and loss of sales (the company declared "force majeure") [10]; the 2011 incident at Rio Tinto's operations, in Australia, that resulted in loss of earnings of $\$ 245$ million; and (v) the extreme rainfalls in Chile, in the first quarter of 2011, that suspended the production of Anglo American's Collahuasi mine, the world's third largest copper mine [30]. Furthermore, a sizable amount of mining activities in countries such as Australia, Canada, Chile, China, South Africa, and the United States of America have increased impacts from climate change, according to 2019 Global Climate Risk Index [33].

Despite the above-mentioned incidents, the current emphasis by the mining sector, so far, has been given to mitigation actions. There are several reasons and challenges behind this reaction. First, the strict Carbon Tax schemes negatively impact the company's balance sheet. Second, the mitigation investments result not only in reduced greenhouse gas emissions, but also in cost savings due to efficiency improvements. Third, there is a major lack of knowledge across mining companies on the financial consequences of climate change and on adaptation indicators or other measures of adaptation effectiveness. This missing piece of information about climate change costs hinders proactive actions, and consequently the sector's adaptation. Nelson et al. [19] argued that there is a knowledge gap among the sector's professionals related to the quantification of potential losses from climate risks. The authors suggest that apart from the physical risks of climate change, the mining industry should pursue a better understanding of the site-level social risks and opportunities, which is an action that will enhance its social license to operate. Acclimatise [28] also stated that the sector needs to shift from extreme (acute) risk management activities to chronic (incremental) changes whose nature is more subtle and whose "impacts may pass undetected until critical thresholds are breached". This management challenge would climate-proof the mining enterprises by incorporating current extremes with the trend of becoming tomorrow's "business as usual", thus being prepared for new higher extremes (adaptation process).

Empirical studies have shown that the mining sector has the ability to adapt within its environment in spite of past adverse historical events [8]. Adaptive management (or governance) offers a new modus operandi for the sector in the face of climate change uncertainties that complements existing risk management measures already implemented in order to minimize climate risks [34]. Landis et al. [35] argued that adapting management actions and interventions in a changing environment can help 
address the factors that hinder effective assessment and managerial actions such as inaccurate scientific assumptions or initial poor process design. Acclimatise [28] and ICF Marbek [29] pointed out that there exist several opportunities for integrating climate risk management tools into existing mining corporate workflow and governance. Therefore, the major quest for the sector is the shift from day-to-day business and dealing with climate change in a reactive and fragmented way to a coherent, proactive, long-term adaptation planning.

All the above-described negative manifestations of climate change on the mining industry call for a prompt implementation of adaptation strategies $[7-11,17,18,26,32,36-42]$ and the development of a practical tool for the assessment of climate change-related economic risks that the extractive companies are facing [5,43]. Specifically, the World Gold Council [43] proposes, as a future area of work, the development of a tool to support the investment community in the context of climate change, provided that risk management is a very useful framework for supporting climate-related decision making [12]. This tool should allow for the analysis of physical risks related to gold mining projects that are comparable with other sectors and asset classes. Furthermore, since major mining projects need external secure financing from institutional investors such as the International Finance Corporation, the European Bank for Reconstruction and Development, Barclay's, and other players in the financial sector, a simple tool for highlighting and prioritizing the risks, vulnerabilities, and possible adaptation measures would be extremely useful for all the sectors involved (mining, insurance, and fiscal). This tool should have, in addition, the capability to address compounding and cascading events [44,45].

In this paper, we introduce an innovative climate change risk assessment framework for mining practitioners, which correlates risk with a mining company's financial outcomes. To the authors' knowledge, it is the first climate change risk assessment model for the mining sector that confronts all the relevant climate change-related hazards that could take place in a mining activity. Furthermore, the proposed framework provides the economic dimension of climate change impacts, can capture adverse as well beneficial effects of climate change in the mining sector, and is well suited for prioritizing potential adaptation strategies. The proposed model can use either qualitative or quantitative input, combining future climate projections data along with expert judgment, and incorporates fuzzy logic to address uncertainty in projected climate changes, as also recommended by the IPCC for policy planning. Our final aim is to establish a robust risk assessment methodology for the mining community that could serve as a decision-making tool for selecting and prioritizing among a range of adaptation actions when dealing with climate change.

The rest of the paper is structured as follows. The following section provides a cohesive literature review on existing methodologies related to climate change vulnerability and more precisely to climate change multi-risk assessment frameworks. Section 3 details the proposed risk assessment framework for the mining industry. Section 4 presents an illustrative example of the model in a hypothetical context. The paper concludes by stressing the advantages of the proposed methodology should it be incorporated in usual mining management practices and some thoughts for future work.

\section{Current State of the Art in Climate Change Multi-Risk Assessments}

Climate change risk identification, assessment, and evaluation formulate the backbone of risk analysis, which, iteratively, with scoping and implementation represent the necessary steps of managing the risk deriving from climate change [12]. Hazard in the climate change context represents the physical phenomenon that might harm, cause damages or losses, or incur risk; generally, it represents the quantification of any possible negative consequences of any hazardous situation to any risk receptor. In the context of climate change, a climate risk represents the risk from one or more climate hazards. According to the number of hazards (single or multiple) and receptors (one or many) under consideration, the process of assessment could be called single or multi-hazard risk assessment for a single receptor and multi-risk assessment for multiple receptors [46].

So far, a number of models and frameworks have been developed toward assessing climate change-related risks on natural and human systems, at the regional and local level. All these efforts 
are in accordance with guidelines issued on behalf of various international and European institutions such as International Standards Organization (ISO) [47,48], or national authorities [49]. For instance, the "CLimate change and Urban Vulnerability in Africa" (CLUVA) framework offers a common way for presenting hazard assessments from multiple sources at regional and local levels, incorporating uncertainties and the assessment of proposed adaptation strategies [50]. The "South East Europe Joint Disaster Management Risk Assessment and Preparedness in the Danube Macro-region" (SEERISK) project presents a framework for local level risk assessment, risk reduction strategies, and risk mapping, using an event tree analysis approach that could be used even in data scarcity situations [51,52]. The "European Spatial Planning Observation Network" (ESPON) project developed a participative multi-hazard approach for climate change vulnerability assessment and mapping on all European territories at regional and local levels [53-55]. The project named "Advanced Terrestrial Ecosystem Assessment and Modelling" (ATEAM) developed a national and regional climate change vulnerability assessment, integrating several ecosystem models and climate change future emission scenarios across Europe [56,57].

The above-mentioned efforts examine all the relevant climate change hazards addressing the needs of many users across sectors. Yet, most of the published climate change-related studies either focus on selected hazards or narrow their range to targeted sectors or scientific communities. Among them, only a few studies focus on the mining sector, such as the study of Rayne et al. [58], who developed a risk-based estimation of climate change effects on mine waste runoff water quality or the study of Chen et al. [59], who created a spatial framework specifically for flooding risk assessment in Australian coal mines, combining several climatic, environmental, and hydrological data obtained from daily time-series observations. Similarly, Liu et al. [60] developed a Geographic Information Systems (GIS)-based methodology for assessing flooding hazard and its impact on coal mines at the regional scale, using Bayesian network and remote sensing techniques.

Other European research initiatives focused on climate change impacts on infrastructures are: the study of Tsavdaroglou et al. [61], who proposed a probabilistic methodology for risk analysis of interdependent critical infrastructures to extreme weather events and the "Risk Management for Roads in a Changing Climate" (RIMAROCC) framework [62], which enables European national authorities to identify road network risks with the associated different action plans and assess the economic implications of each action taking into consideration implementation, maintenance, and environmental factors. Canadian authorities developed corresponding frameworks such as the Canadian public infrastructure risk assessment methodology named "Public Infrastructure Engineering Vulnerability Committee (PIEVC) Engineering Protocol for Infrastructure Vulnerability Assessment and Adaptation to a Changing Climate" [63,64] or the model of Etkin et al. [65], which focused on the permafrost thawing impacts on engineering design and infrastructures. Kontogianni et al. [24] developed a vulnerability framework focused on the implication of climate change to small harbors, taking into consideration geophysical and socioeconomic parameters. Jäger et al. [66] developed a decision support system (DSS) for predicting onshore hazards and coastal impacts using evidence of past storm scenarios and known land use-vulnerability relationships such as damage curves. Finally, Zhou et al. [67] introduced an integrated urban flood risk assessment framework that incorporates climate change impacts, inundation models, and adaptation options cost assessment.

Gallina et al. [46] performed an extensive review of multi-hazard, multi-hazard risk, and multi-risk methodologies used in the context of climate change. They argue that the long-term effects of climate change have not been adequately integrated (most methodologies focused on multi-hazard assessment without considering changes in space or time). The authors propose that for climate change risk assessments, one should integrate qualitative (with expert opinions, as well as stakeholder and participatory involvement) and quantitative methods (e.g., climate modeling, statistic handling of uncertainties, and GIS).

The review on the state-of-the-art research on climate change risk assessments revealed a number of frameworks that examine risk and vulnerability notions across diverse contexts and scales (i.e., 
in relation to climate change, natural and man-made hazards, disaster loss reduction, and at the national, regional, or local level). Well-developed multi-risk frameworks (such as SEERISK) and multi-hazard risk ones (such as ESPON) belong to a series of research initiatives funded by European Commission (EC) involving universities, academia, research centers, organizations, and scientists mainly in Europe. Irrespective of their origin, though, very few frameworks attempt a deterministic quantification of examined impacts, and more precisely, the research effort of Tsavdaroglou et al. [60]. Nevertheless, these frameworks neglect to quantify and to incorporate in their economic output the various uncertainties either from climate projections or from missing data. Furthermore, to the best of our knowledge, there is no existing framework developed for financial institutions of any size that examines climate change risks in a multi-hazard or multi-risk level, taking into consideration the total estimated financial risk of climate change and correlating it with the viability of the impacted institution. A few studies propose a flexible framework for either qualitative or quantitative assessments dependent on the available data, such as RIMAROCC. Finally, a few frameworks incorporate and prioritize adaptation strategies (such as CLUVA and RIMAROCC). Even fewer explicitly deal with uncertainty and fuzziness such as CLUVA and RIMAROCC, as most climate change risk assessments are based on deterministic models. In relation to the mining sector, scientific efforts have focused on climate change single-hazard risk assessments (mainly mine flooding mishaps). Eventually, linking to the aim of the present study, there is a lack of a comprehensive framework that could assess climate change-related risks for all the subcomponents of the mining industry at a mine-site (i.e., local) level. Ideally, a proposed framework should combine future scenario-driven (top-down) approaches at the local level with vulnerability-driven approaches for addressing long-term vulnerability and the assessment of pre-emptive adaptation responses [68].

\section{The CLImate Change Economic Risk in the Mining Industry (CLIRMI) Model}

\subsection{General Description of the Model}

The present study introduces a probabilistic risk model that: (i) assesses multiple climate hazards concurrently and structured in a process-oriented way; (ii) estimates the overall risk as a function of the financial implications of climate change impacts (either in annual monetary damages or as a percentage loss of annual turnover); (iii) is able to capture adverse as well beneficial effects of climate change in the mining sector; and (iv) is well suited for prioritizing potential adaptation strategies. CLIRMI is the first multi-risk model (this implies that it is also multi-hazard and multi-vulnerable) dedicated to mining and one of the few, in general, that tries to assess climate change-related risks and their financial outcomes on the activity under investigation. The proposed framework is open in order to easily add, upgrade, and swap components. For instance, it is possible to include or exclude from the analysis site-specific hazards, vulnerabilities, and adaptation strategies. According to Bradley [69], a common method for measuring the importance of a hazard is by assessing the probability of hazard occurrence and its impacts in case it takes place. The likelihood and severity can be calculated using existing analytical data (e.g., sufficient data from past time series) or expert opinion if past data is scarce or inexistent. In such cases, experts can intuitively express their perceptions based on their past observations, history, knowledge, and experiences from on-the-field jobs [69]. To this end, CLIRMI provides the user with the flexibility of conducting the analysis by means of quantitative data, e.g., future occurrences of climatic events from climate models, probabilities of the destruction of mine systems, economic damage per incident, etc., or by using qualitative expressions of triggering conditions, event probabilities and consequences, etc. The former requires the use of a hybrid Bayesian belief network (BBN), while the latter can be implemented with a discrete BBN. However, in either case, expert judgment is required. Finally, CLIRMI is based on a probabilistic graph network incorporating fuzzy logic, so as to address the uncertainty inherently involved in future climate, the likelihood and the consequences of adverse impacts, etc. 


\subsection{A Concise Introduction to Bayesian Belief Networks}

A BBN is a graphical probabilistic model that has numerous applications in the domains of artificial intelligence, machine learning, risk analysis, and environmental modeling, among many others. This statistical multivariate model connects a set of random discrete, continuous, or both variables $\left(X_{1}\right.$, $\left.X_{2}, \ldots, X_{n}\right)$ in a joint probability distribution (JPD), allowing the extraction of probabilistic relationships among the variables. If one or more variables become known, e.g., after available observations or the elicitation of experts, the BBN calculates the effect of this information (called "evidence") on the probability distributions of all the other variables. If the model is relatively small, variable updates in distributions are performed instantly, permitting a clear and intuitive representation of the relationships among variables [70]. Thus, applications of BBNs have recently become popular for decision support systems (DSS) for natural hazards and as negotiation and discussions tool among decision-makers, experts, and stakeholders [66]. According to Zerrouki and Smadi, [71] the ability of BBNs to diagnose causation as well to infer based on proper evidence makes them perfect for quantitative risk analysis.

A BBN is comprised of two parts:

1. The qualitative part, which is a direct acyclic graph (DAG) where each node represents each one of the variables of the model. The nodes are connected by directed arcs indicating a conditional correlation between connected nodes. A node that receives an arc end is called a "child" node of the relevant "parent" node; thus, the direction of influence from parent to child is implied. Nodes and arcs comprise the elements of the network that cannot form a cyclic path, meaning that there must not be any path from node $X_{i} \rightarrow \ldots \rightarrow X_{i}$ for any $i:\{1, \ldots, n\}$; and

2. The quantitative part, which is the conditional probability distribution of each variable $X_{i}$ given its parents $\left(\mathrm{pa}\left(X_{i}\right)\right)$. The conditional probability distribution is expressed in conditional probability tables (CPTs) for discrete variables or in probability functions for continuous variables [72]. Finally, the JPD $P\left(X_{1}, X_{2}, \ldots, X_{n}\right)$ through the chain rule is factorized as follows expressed alternatively:

$$
f_{X_{1}, X_{2}, \ldots, X_{n}}\left(x_{1}, x_{2}, \ldots, x_{n}\right)=\prod_{i=1}^{n} f_{X_{i} \mid p a\left(X_{i}\right)}\left(x_{i} \mid X_{p a\left(X_{i}\right)}\right)
$$

or:

$$
P\left(X_{1}, X_{2}, \ldots, X_{n}\right)=\prod_{i=1}^{n} P\left(X_{i} \mid p a\left(X_{i}\right)\right)
$$

where $X_{p a(X i)}$ or $p a\left(X_{i}\right)$ is the set of parent nodes of $X_{i}$, with $i=1,2, \ldots, n$.

BBNs compute probabilities using algorithms based on Bayes' theorem. For a given set of two variables $X_{1}, X_{2}$, the theorem states:

$$
P\left(X_{1} \mid X_{2}\right)=\frac{P\left(X_{2} \mid X_{1}\right) P\left(X_{!}\right)}{P\left(X_{2}\right)}
$$

where $P\left(X_{1} \mid X_{2}\right)$ that reads " $X_{1}$ given $X_{2}$ " is called posterior distribution and has the meaning of the updated distribution of node $X_{1}$ taking into account new evidence on node $X_{2} ; P\left(X_{2} \mid X_{1}\right)$ is the CPT of node $X_{2}$, and $P\left(X_{1}\right)$ and $P\left(X_{2}\right)$ are the probabilities of $X_{1}$ and $X_{2}$ respectively, according to Jäger et al. [66].

The BBN approach was selected for the development of CLIRMI, mainly, for three reasons [70-90]: (i) BBNs incorporate complex relationships and various uncertainties, which originate from model assumptions, parameters interrelationships, climate projections, empirical data, or expert knowledge; (ii) BBNs can be used in a qualitative or quantitative context in conjunction with expert opinions; and (iii) BBN software tools permit the development of a modular and open-architecture framework that could be easily modified, integrated, or expanded to a decision support system. According to Castelletti and Soncini-Sessa [83], BBNs are extremely useful in cases where we have little knowledge of what needs to be modeled, i.e., there is no quantitative model of the way the system works based on empirical data, and the only information we have is subjective stakeholder evaluations or 
historical frequency data. In such cases, organizing available knowledge in a BBN is the best way for explicitly incorporating structural uncertainty (i.e., the unknown unknowns or process noise). BBNs are often used in environmental modeling. To wit, Marcot et al. [84] and Uusitalo [85] review many BBN applications in the context of ecology. Further, Landuyt et al. [86] referred to the use of BBNs in ecosystem services, and Varis and Kuikka [87] focused on resource and environmental management applications. Catenacci and Giupponi [88] and Sperotto et al. [89] reviewed existing BNs environmental management applications and argued that BNs could play a crucial role in climate change risk assessments due to their increased capacities of multi-risk, uncertainty, and scenario analysis handling. In the same direction, Aguilera et al. [90] argued that there is still significant and unexploited potential. The suitability of BBNs for modeling risks in the context of climate change is also supported by the plethora of applications in the scientific literature [72-82].

\subsection{Fundamental Assumptions}

\subsubsection{Time, System, and Context Boundaries}

Even though climate change affects the mining industry as well as the surrounding environment in which it operates, the social and ecological/environmental systems are implicitly excluded from the analysis. Nevertheless, social and environmental impacts resulting from the mining project as a consequence of climate-related accidents are considered in the analysis, e.g., by estimating potential liabilities.

The spatial boundaries of the analysis are set by the mine subcomponents, which are presented hereinafter, and are affected by climate change. At this level, i.e., local, the impacts of climate change on mining operations can be better observed and analyzed. The system's boundaries may be extended beyond the mine site in case climate-related accidents could harm the surrounding man-made and natural environment.

The development, extraction, and closure works of surface and underground mining, with mineral processing activities included (apart from smelting), are examined as directly affected by climate-related hazards [91]. According to Hodgkinson et al. [38], production, post-production, and reclamation are the most affected among the five mine lifecycle stages. Focusing on those two stages through a systems-theory lens, mining works could be seen as a coordinated set of five interacting mining subsystems, as shown in Table 1. This approach allows also for a more targeted selection of potential adaptation measures. It is noted that the early stages of the life cycle of a mine, e.g., exploration and mine design and planning, are considered far less prone to climate hazards, and their inclusion would increase unreasonably model complexity. Therefore, they are not included in the analysis.

Finally, to set the appropriate time frame, a typical mine lifecycle and uncertainties of long-term projections are considered. According to Hodgkinson et al. [32], a typical mine-life ranges from eight to over 40 years. Further, most climate models incorporate a mid-century scenario for future climate projections. Hence, our framework suggests a timeframe of up to 40 years, unless otherwise required (e.g., if the mine-life extends beyond 40 years).

\subsubsection{Climate-Related Hazard Events}

A review of the relevant literature identified the following climate change-related threats to mining activities $[5,8,16,19,40,92,93]$ :

1. Landslides, where different kind of mass movements are included i.e., mudflows or debris flows, landslides, landslips, and rockfalls

2. Flooding events (flash floods and river floods)

3. Cyclones, extreme winds, and storm surges where coastal flooding is included

4. Wildfires

5. Heat waves

6. Cold spells 
7. Sea level rise (SLR)

8. Permafrost thaw

9. Droughts and water scarcity

Our proposed framework examines only the first six hazards, which are seen under the umbrella of extreme weather events, namely: landslides; floods; cyclones, extreme winds and storm surges; wildfires; heat waves; and cold spells.

Slow onset events as defined in United Nations' Framework Convention on Climate Change (UNFCCC)'s technical paper [94], such as SLR, increasing temperature patterns, glacial retreat, permafrost thaw, desertification, and drought (although an extreme weather event per se, it is closely related to land degradation and desertification), are outside of the scope of the model. The assumption behind this choice is that such events evolve gradually over the years, permitting the mining industry to promptly design and implement appropriate adaptation actions [8]. For instance, in order to combat drought phenomena, mining companies adopt measures such as wastewater recycling, seawater desalination, worked water storage increase, water losses reduction, the use of drought-resistant and native plant species in rehabilitation projects, etc. [19,93-100]. Similarly, mines operating in Canadian Arctic regions in order to deal with permafrost thaw in infrastructure foundations (such as tailing ponds or water treatment facilities) use thermosyphons, insulation, or other reinforcement techniques [101].

Table 1. Subsystems of the mining industry considered in the present framework.

\begin{tabular}{|c|c|c|}
\hline Mining Subsystem & Processes & Assets, Equipment, and Infrastructure \\
\hline $\begin{array}{l}\text { Extraction (hereafter } \\
\text { indicated using a } \\
\text { numerical index S1) }\end{array}$ & $\begin{array}{l}\text { Stripping, drilling and } \\
\text { blasting, overburden removal, } \\
\text { and ore extraction }\end{array}$ & $\begin{array}{l}\text { Mine quarry, drills, draglines, excavators, } \\
\text { shovels, dozers, graders, etc. }\end{array}$ \\
\hline Transportation (S2) & $\begin{array}{l}\text { Ore, wastes and products } \\
\text { transportation (i.e., loading, } \\
\text { hauling, transporting, } \\
\text { conveying, shipping and } \\
\text { unloading of ore, wastes, } \\
\text { semi-finished and finished } \\
\text { products) }\end{array}$ & $\begin{array}{l}\text { Excavators, loaders, shovels, dump trucks, } \\
\text { conveyors, ducts, pipes, marine (un)loading } \\
\text { ports/facilities, airport strips, road and rail } \\
\text { networks, electricity production stations, } \\
\text { electricity and telecommunications networks, } \\
\text { fuel stations, water tanks, fuel and water } \\
\text { networks }\end{array}$ \\
\hline \multirow{2}{*}{$\begin{array}{l}\text { Processing/beneficiation } \\
\text { (S3) }\end{array}$} & \multirow{2}{*}{$\begin{array}{l}\text { Size reduction, size separation, } \\
\text { concentration, dewatering and } \\
\text { aqueous dissolution }\end{array}$} & $\begin{array}{l}\text { Sites and factories, ponds, piles, dumps and } \\
\text { silos, conveyors, ducts, pipes, loaders, dump } \\
\text { trucks. Assets for; } \\
\text { (i) size reduction: crushers, mills, }\end{array}$ \\
\hline & & $\begin{array}{l}\text { (ii) size separation: classifiers, cyclones, } \\
\text { vibrating screens, } \\
\text { (iii) concentration: flotation, shaking tables, } \\
\text { (iv) dewatering: thickeners, filters, } \\
\text { centrifuges. }\end{array}$ \\
\hline Wastes management (S4) & $\begin{array}{l}\text { Overburden and tailings } \\
\text { management }\end{array}$ & $\begin{array}{l}\text { Mine quarry, waste piles, dumps, tailing } \\
\text { ponds, excavators, loaders, dozers, graders, } \\
\text { dump trucks, ducts, pipes }\end{array}$ \\
\hline Rehabilitation (S5) & $\begin{array}{l}\text { Rehabilitation and monitoring } \\
\text { of disturbed areas }\end{array}$ & $\begin{array}{l}\text { Mine quarry, rehabilitated works, waste piles, } \\
\text { dumps, tailing ponds, excavators, loaders, } \\
\text { dozers, graders, dump trucks, ducts, pipes }\end{array}$ \\
\hline
\end{tabular}

\subsubsection{Triggering Climatic Events}

Each of the selected climate-related hazards is associated with one (or more) "Triggering Climatic Events" (TCEs). TCEs depend to a greater or lesser extent on site-specific conditions and various meteorological parameters, such as those presented in Table 2. The readers are cautioned that the presented TCEs for each associated hazard are intended to be illustrative of the range of potential TCEs 
that could be used when setting up the model, and should not be considered as an inherent feature of the model.

\subsubsection{Vulnerability}

There is no commonly accepted definition nor are there any metrics of climate change vulnerability [102]. Various approaches exist for measuring vulnerability, such as proxy indicators, direct elicitations, etc. [103]. Kasperson and Kasperson [104] accounted for 27 different notions of vulnerability, each one relevant to the scientific context into which it appears. This phenomenon could be rooted in the diverse scientific lineages of the various researchers and the diverse background between social and natural scientists [105]. On top of these obstacles, it is noted that vulnerability is a subjective phenomenon, dynamic in nature, and time and place-dependent [103].

The most recent WG2 Report of AR5 took a step toward a wider definition of vulnerability of human and environmental systems than previous reports, stating that "vulnerability encompasses a variety of concepts and elements including sensitivity or susceptibility to harm and lack of capacity to cope and adapt" [12]. For this framework, the focus is on contextual vulnerability, which presents the inability of mining operations to cope with external pressures or changes, such as changing climate conditions. 
Table 2. Site-specific factors relating to hazards under investigation. TCEs: Triggering Climatic Events.

\begin{tabular}{|c|c|c|c|c|}
\hline Hazard & Site-Specific Factors & Meteorological Conditions & Indicative TCEs & References \\
\hline $\begin{array}{l}\text { Landslides } \\
\text { (hereafter } \\
\text { indicated using } \\
\text { the letter A) }\end{array}$ & $\begin{array}{l}\text { Topographic (slope length, convexity, } \\
\text { direction/aspect, steepness), geological (lithology, } \\
\text { soil type, geomorphological zone, seismicity), land } \\
\text { cover (deforestation, effects of human activities), } \\
\text { hydrological (river density and proximity) }\end{array}$ & $\begin{array}{l}\text { Duration and intensity of } \\
\text { event rainfall along with the } \\
\text { intensity of antecedent rainfall }\end{array}$ & $\begin{array}{l}\text { Maximum one-day precipitation with maximum consecutive } \\
\text { five-day precipitation (Rx1day and Rx5day) } \\
\text { Simple daily precipitation intensity index (SDII) } \\
\text { Number of very heavy precipitation days (R20) } \\
\text { Annual count of days when precipitation exceeds nn mm (Rnn) } \\
\text { Annual total precipitation and maximum wet spell (R95pTOT } \\
\text { and Consecutive Wet Days, CWD) }\end{array}$ & {$[38,92,106-109]$} \\
\hline Floods (B) & $\begin{array}{l}\text { Topographic (elevation, slope length, convexity, } \\
\text { direction/aspect, steepness), geology, land cover } \\
\text { (deforestation, effects of human activities), } \\
\text { hydrological (river density and proximity) }\end{array}$ & $\begin{array}{l}\text { Duration and intensity of } \\
\text { event rainfall }\end{array}$ & $\begin{array}{c}\text { Maximum one-day precipitation (Rx1day) } \\
\text { Number of very heavy precipitation days (R20) } \\
\text { Annual count of days when precipitation exceeds } \mathrm{nn} \text { mm (Rnn) } \\
\text { Annual total precipitation (R95pTOT) }\end{array}$ & {$[10,59,109-112]$} \\
\hline $\begin{array}{l}\text { Windstorms, } \\
\text { storm surges }(C)\end{array}$ & Site location (elevation, coast proximity) & $\begin{array}{l}\text { Wind speed and wind } \\
\text { direction }\end{array}$ & $\begin{array}{c}\text { Average wind speed } \\
\text { Gusts wind speed }\end{array}$ & {$[109,113]$} \\
\hline Wildfires (D) & Forest coverage (soil coverage, land use, fuel type) & $\begin{array}{l}\text { Daily maximum temperature, } \\
\text { minimum relative humidity, } \\
\text { precipitation, maximum } \\
\text { wind speed }\end{array}$ & $\begin{array}{c}\text { Max Tmax and wind gust speed above the } 90^{\text {th }} \text { per. } \\
\text { (TXx and gust winds }>90^{\text {th }} \text { per.) } \\
\text { Warm days (Tx } 90 \mathrm{p} \text { ) } \\
\text { Warm Spell Duration Index (WSDI). }\end{array}$ & {$[109,114-118]$} \\
\hline Heat waves (E) & $\begin{array}{l}\text { Site location (latitude). Process and assets } \\
\text { exposure to excessively high temperatures }\end{array}$ & Daily maximum temperature & $\begin{array}{c}\text { Warm days (Tx90p) } \\
\text { Warm Spell Duration Index (WSDI) } \\
\text { Summer days (SU25) }\end{array}$ & {$[109,119,120]$} \\
\hline Cold spells (F) & $\begin{array}{l}\text { Site location (latitude). Process and assets } \\
\text { exposure to excessively high temperatures }\end{array}$ & Daily minimum temperature & $\begin{array}{c}\text { Cool days (Tx10p) } \\
\text { Cold Spell Duration Index (CSDI) } \\
\text { Frost days (FD0) }\end{array}$ & [109] \\
\hline
\end{tabular}




\subsection{Development of the CLImate Change Economic Risk in the Mining Industry Model}

The first step toward developing the BBN model was the construction of the conceptual model, which is illustrated in Figure 1.

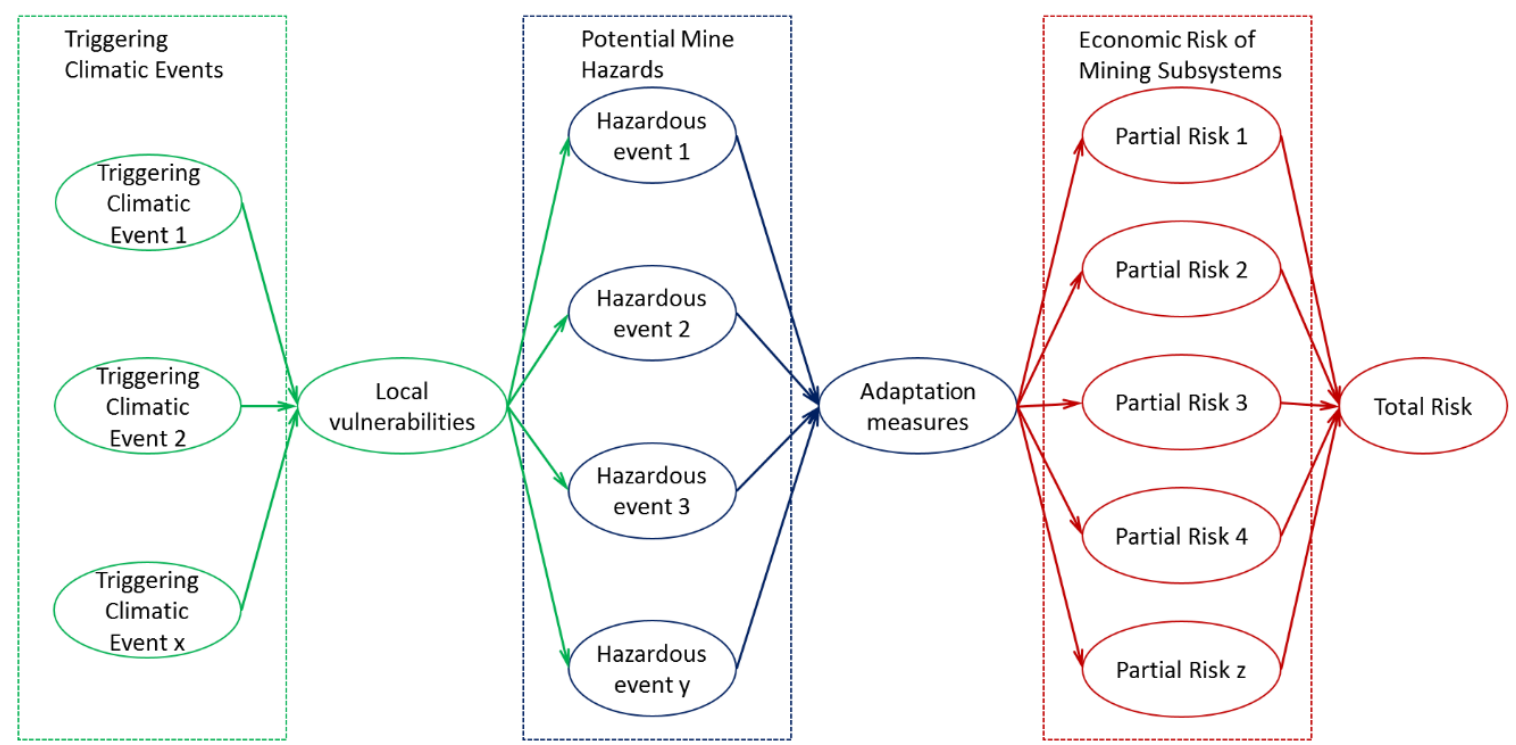

Figure 1. Conceptual model of CLImate Change Economic Risk in the Mining Industry (CLIRMI).

Risk is conceptualized as a function of vulnerability to a number of climate-related hazards, existing or planned adaptation measures, and expected damages should a hazard occurs. The conceptual model assumes that each hazard is caused by a relevant TCE and is affected by local vulnerabilities (first cause-effect relationship). A hazard may not affect all the mining subsystems of the mining project. Further, if the subsystem can adequately respond to the consequences of the hazard (i.e., there is enough adaptive capacity), then no consequences will be manifested (second cause-effect relationship). However, when a hazard adversely affects any subsystem, then the severity of its consequences defines the risk that the hazard poses to the subsystem (third cause-effect relationship). Mathematically, the above conceptualization is stated as follows:

$$
H_{i}=f\left(T C E_{i}, V_{i}\right)
$$

and

$$
R=f\left(A_{i},\left(S_{i}\right)_{j}, H_{i}\right)
$$

where $H_{i}$ is the annual probability for hazard $i$ (where $i$ : Landslide- $\mathrm{A}$, Flood-B, Windstorms-C, Wildfires-D, Heat waves-E, and Cold spells-F) and $R$ is the total risk, that is the financial implications of climate change impacts (expressed either in annual monetary damages or as a percentage loss of annual turnover). Furthermore, $T C E_{i}$ is the specific climatic event that triggered hazard $i, V_{i}$ is the vulnerability to hazard $H_{i} ; A_{i}$ is the adaptation to hazard $H_{i}$; and $S_{i j}$ represents the consequences of hazard $H_{i}$ to subsystem $j$ (where $j$ : Extraction-S1, Transportation-S2, Processing—S3, Waste-S4, and Rehabilitation-S5).

\subsubsection{Discrete Bayesian Network}

The conceptual model was converted into a probabilistic BBN using the GeNIe Modeler software [121]. In discrete Bayesian networks, all the nodes represent discrete variables that take values from a finite set, and the conditional probability distributions are expressed in conditional probability tables (CPTs), as discussed in Section 3.2. The probabilistic model was the preferred method over the deterministic one, given that it involves complex and uncertain interactions between its variables [122]. 
The general layout of the CLIRMI BBN, which is shown in Figure 2, includes the following groups of nodes: "TCEs", "Vulnerability", "Hazards", "Adaptation", "Mining Subsystems", "Subsystem Risks", "Total Risk", "Probability of Hazards Occurring on Subsystems", "Severity of Impacts on Subsystems", and "Partial Risks" (which are contained in the "Partial Risks Calculation" subnetwork not presented here).

The first two rows of the BBN (Figure 2) include the "TCEs" nodes, which are expressed as annual probability of occurrence, and the "Vulnerability" nodes (measured using a nominal scale of four categories, i.e., "negligible", "low", "medium", and "high" (with "negligible" referring to invulnerable sites regarding the specific TCE). "TCE" and "Vulnerability" are the "parent" nodes of the six climate-related "Hazards" nodes of the third row (first cause-effect relationship). The "Hazards" nodes are also expressed as the annual probability of occurrence. In the case of absence or limited availability of data, or when a "fast-track" analysis is required, the user may omit the top two "parent" nodes and start directly from the "Hazards" nodes. Mathematically, each "Hazard" node expresses the annual occurrence probability of each hazard based on the conditional probability of each "TCE" given the relevant "Vulnerability".

Following, the fourth row of Figure 2 includes the "Adaptation" nodes. This is a group of "orphan" nodes where the level of adaptation measures that the mine operator has adopted or plans to take in order to minimize climate change adverse impacts are defined by means of a four-class scale ("absent", "low", "medium", and "high", with "absent" referring to a complete absence of adaptation). The fifth row represents the "Mining Subsystems" group of nodes. For calculation purposes, these five "orphan" nodes take only two values, "no" and "yes", with "no" denoting the absence of the relevant subsystem. The "Hazard", "Adaptation", and "Mining Subsystems" nodes act as "parents" for the "Probability of Hazards Occurring on Subsystems" group of nodes.

Each node of "Probability of Hazard Occurring on Subsystem" (PHOS) expresses the annual probability of occurrence of the hazard affecting the subsystem in question. This group and the "Severity of Impacts on Subsystems" (SIS) group of nodes (expressed as economic losses per hazard occurrence) are included inside the "Partial Risks Calculation" subnetwork of nodes not shown here. These last two groups of nodes are combined to estimate the "Partial Risks" (i.e., risks related to the specific hazards of each subsystem). Finally, the "Partial Risks" are summed into "Subsystem Risk", and then the five "Subsystem Risks" are combined into a single "Total Risk". The aggregation of the six "Partial Risk" nodes into a total "Subsystem Risk" node for every subsystem is performed with the parent divorcing method [123-125]. The same method is used for the final aggregation of the five "Subsystem Risk" nodes to a "Total Risk" node [126]. As previously noted, "Risks" nodes are expressed as economic losses on an annual basis, i.e., annual monetary damages or as a percentage loss of annual turnover.

The names of the classes and the values used in the discrete CLIRMI BBN for the calculations on the CPTs of "TCEs", "Hazards", and "Probability of Hazards Occurring on Subsystems" nodes are described in Table 3, and the class names and used values of "Severity of Impacts on Subsystems", "Partial Risk", and "Total Risk" nodes are given in Table 4, respectively.

Inside the "Partial Risks Calculation" subnetwork, there are five sets of nodes: one for each mining subsystem. Referring only to the first set, dedicated for the "ore extraction" subsystem, the first row is the group of "Probability of Hazards Occurring on Subsystems" (PHOS) nodes where each node, as previously explained, has three "parent" nodes (i.e., "Hazard", "Adaptation", and respective "Mining Subsystem") not presented in the subnetwork in order to reduce the complexity of the structure of the main part of the model. Each PHOS node for the "extraction" subsystem represents the conditional annual probability of occurrence of the hazard that affects the subsystem "ore extraction". As previously mentioned, PHOS nodes have similar classes and class names as the "TCE" and "Hazard" nodes presented in Table 3, and mathematically express hazard probability (annual probability of occurrence) for every subsystem given the adaptation measures (second cause-effect relationship). 


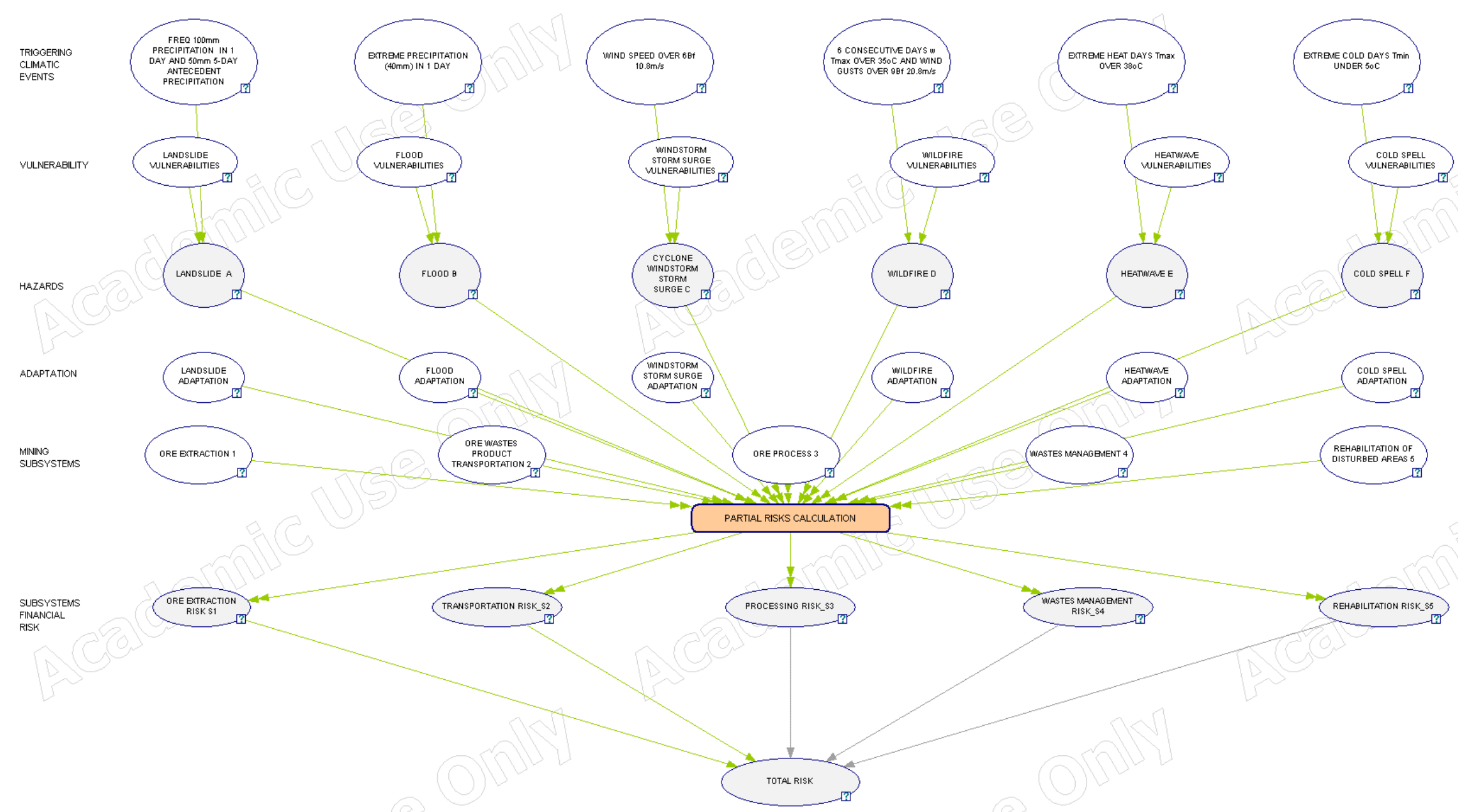

Figure 2. General layout of the CLIRMI Bayesian belief network (BBN). 
Following, the second row represents the group of "Severity of Impacts on Subsystems" (SIS) "orphan" nodes for the "ore extraction" subsystem. According to Bradley [69], impacts can be measured using a variety of metrics such as lost revenue, operating cost, and downtime duration. In our framework, annual revenue loss in percentage metric was selected, as it expresses the economic adverse consequences of climate change impacts, permitting a multi-risk view with a later aggregation of several impacts into a total economic risk. Each SIS node is composed of nine classes, the name and values of which for the calculations on CPTs are presented in Table 4. These classes were set after reviewing publicly available past climate change impacts and extreme weather-related disasters in mining companies in Australia and Canada $[8-10,16,30,32,38,69,127]$. The third row represents the group of "Partial Risk" nodes for the subsystem that is directly influenced by the "parent" nodes (third cause-effect relationship). As mentioned, the proposed framework conceptualizes risk as to the product of hazard probability and hazard severity. All the risk nodes (i.e., "Partial Risk", "Subsystem Risk", and "Total Risk") have similar classes and names to SIS nodes (Table 4).

Table 3. Discrete classes of "TCEs", "Hazards", and "Probability of Hazards Occurring on Subsystems" nodes used in the discrete model (expressed as annual probability of occurrence).

\begin{tabular}{ccc}
\hline Verbal Expression & Default Annual Probability & Base Values for Risk Calculation \\
\hline Negligible & $<0.1 \%$ & 0 \\
\hline Highly Unlikely & $1 \%$ & 0.01 \\
\hline Remotely Possible & $5 \%$ & 0.05 \\
\hline Possible & $10 \%$ & 0.1 \\
\hline Somewhat Likely & $20 \%$ & 0.2 \\
\hline Likely & $40 \%$ & 0.4 \\
\hline Probable & $70 \%$ & 0.7 \\
\hline Highly Probable & $100 \%$ & 1 \\
\hline Remarkably Probable & $>100 \%$ & 4 \\
\hline
\end{tabular}

Table 4. Discrete classes of the "Severity of Impacts on Subsystems", "Partial Risk", "Subsystem Risk", and "Total Risk" nodes used in the discrete model (expressed as percentage loss of annual turnover).

\begin{tabular}{ccc}
\hline Verbal Expression & $\begin{array}{c}\text { Expressed as \% of Annual } \\
\text { Revenues }\end{array}$ & $\begin{array}{c}\text { Base Values for Partial Risk } \\
\text { Calculation Node }\end{array}$ \\
\hline No Effect & 0 & 0 \\
\hline Negligible & $<0.01 \%$ & 0.0001 \\
\hline Measurable & $0.01-0.1 \%$ & 0.001 \\
\hline Minor & $0.1-0.5 \%$ & 0.005 \\
\hline Moderate & $0.5-1 \%$ & 0.01 \\
\hline Major & $1-2 \%$ & 0.02 \\
\hline Serious & $2-4 \%$ & 0.04 \\
\hline Significant & $4-5 \%$ & 0.05 \\
\hline Hazardous & $5-10 \%$ & 0.1 \\
\hline Devastating & $>10 \%$ & 0.5 \\
\hline
\end{tabular}

\subsubsection{Hybrid Bayesian Network}

In the above presented discrete Bayesian network, the final risk outcome is presented in economic terms in a semi-quantitative form, as a percentage of annual revenue loss. Nevertheless, the risk could be expressed in another even more quantitative way. Specifically, we claim that by replacing the 
discrete nodes of "Severity of Impacts on Subsystems" and "Partial Risk" with continuous nodes of triangular (or other user-selected) distributions, then the outcome risk could be expressed in purely monetary terms as a probability distribution in a fuzzy form (e.g., from a minimum amount " $l$ " (low) to a maximum " $h$ " (high) with more likely amount " $m$ " (mode), if a severity expression of triangular distribution is selected).

In this case, the proposed modified framework is a hybrid Bayesian network where discrete and continuous variables coexist $[121,128]$. Each "Partial Risk" node is a continuous node, calculated as the product of a PHOS discrete node and a SIS continuous node. The set of five partial "Subsystem Risk" and the "Total Risk" continuous nodes are simple aggregation functions of probability distributions. This special type of hybrid BN is called conditional linear Gaussian network (CLGN) [123,124,128]. In the proposed framework, for the implementation of the hybrid version, the end user simply inserts the necessary values of the desired distribution directly in the equation box of each SIS node.

\section{Illustrative Example}

The proposed climate change risk assessment framework is implemented by a team of professionals ideally made up by climate, geotechnical, hydrogeology, and mining experts, and builds on their knowledge, values, and experience $[68,129]$. Given that the multidisciplinary expert team uses the proposed CLIRMI framework on behalf of and for the benefit of the mining corporation under analysis, it follows that it is for the corporation's best interest that the necessary expertise and the most appropriate range of scientific specializations is assured according to the performed operations. Therefore, scientific specialization with hands-on experience on the fields of climatology/meteorology, geology, hydrology, coastal erosion (for coastal activities), etc. are definitely mandatory. In environmental modeling, often parameter estimation is achieved using experts' subjective knowledge. The goal of this multidisciplinary process is to arrive at an agreed compilation of the necessary inputs for the model through documented, informed judgments, the use of directly relevant knowledge (environmental, scientific, engineering, operational, or local), and a sharing of collective views [64,68,129]. Examples of such procedures are already part of the mining industry decision-making process [101] and EC-funded projects for climate change adaptation research.

Hereinafter, an illustrative example of the CLIRMI framework is presented using a hypothetical case study. The theoretical CLIRMI mine is an industrial minerals mining company located in a small island named Virtualislet. Virtualislet has a total surface of $100,000 \mathrm{~km}^{2}$ and mild relief; its tallest mountain is below $400 \mathrm{~m}$. CLIRMI mine operates at the center of the island, and is a 50-ha open pit bentonite quarry where only mechanical extraction and loading is performed without any size reduction due to material properties. However, numerous-more than 30 so far-mine benches are stable due to the coherent deposit and absence of geologic soil faults. Extracted material (around $90 \mathrm{ktpa}$ ) is loaded to haul trucks and transported to open-air storage areas. Then, the run-of-mine (ROM) material once again is loaded to haul trucks and transported to the port facility where with the use of mobile mechanical equipment (loaders, feeders, and conveyor belts) is finally led to mid-capacity bulk carrier vessels on a monthly basis. CLIRMI mine has an annual gross revenue of around five million euros, a total unit cost of $45 € / \mathrm{tn}$, and an average sale price of $55 € / \mathrm{tn}$, permitting an annual gross profit of 900,000 Euros.

The above-described theoretical mining activity is assumed to be impacted by the following climate-related hazards: flooding of the mine, haul road damages with transportation disruptions, and increases in product waste during intense downpours. Further, extreme winds and storm surge negatively affect port facilities and delay ship loadings. Finally, heat waves affect working conditions, during which production ceases with a subsequent loss of production and transportation decline. Therefore, the following three hazards are considered: (i) flooding, (ii) extreme winds or storm surges, and (iii) heat waves. These hazards affect both ore extraction and product transportation mine subsystems. Each of these hazards, as discussed in the Section 3.3.3 titled "Triggering Climatic Events", are associated with certain TCEs. The team of professionals after reviewing historic climate data, mine 
adverse climatic manifestations, impacts, and local factors defined that for the described hazards, the associated TCEs are: (i) daily rainfall above the $40-\mathrm{mm}$ threshold; (ii) wind gust speed above $10.8 \mathrm{~m} / \mathrm{s}$; and (iii) daily maximum temperature above the temperature threshold of $38^{\circ} \mathrm{C}$.

According to the A1B IPCC climate scenario, for the mid- $21^{\text {st }}$ century period, for the imaginary region and in relation to the historic period between 1961-1990, there seems to be a 135\% increase of rainfall events above the $40-\mathrm{mm}$ threshold, a $1.6 \%$ increase of wind gust speeds greater than $10.8 \mathrm{~m} / \mathrm{s}$, and a $115.7 \%$ increase of days with $\mathrm{T}_{\max }$ above the $38{ }^{\circ} \mathrm{C}$ threshold. After reviewing these projections, the experts estimate the annual likelihood probability for each of the three TCEs causing the hazards under consideration. The projected rainfall increase means that for the future 30-year period of the analysis, rainfall events above the 40-mm threshold are estimated to occur 14 times in total. Therefore, the annual likelihood probability of such rainfall events, i.e., $46 \%$, is expressed as a combination of the discrete classes of Table 3, namely $80 \%$ likely and 20\% probable. Furthermore, extreme winds and heat waves are estimated to occur, annually, seven and 12 times, respectively, making both events $100 \%$ remarkably probable (Table 5). Then, assuming that each hazard does occur, the experts estimate the economic impact per incident on every mining subsystem in two different forms: as a percentage of annual revenues and as net monetary losses in a probabilistic form, i.e., the minimum, average, and maximum expected amount of money (Tables 6 and 7, respectively). It is noted that for the solution of the discrete BBN, the data of Tables 5 and 6 are used, whereas for the CLGN model, the data of Tables 5 and 7 are used.

Table 5. Expected annual likelihood for anticipated hazards for CLIRMI mine.

\begin{tabular}{|c|c|c|c|}
\hline \multirow{2}{*}{ Qualitative Expression } & \multicolumn{3}{|c|}{ Likelihood Probability for Each Hazard } \\
\hline & Flooding & Extreme Winds & Heat Waves \\
\hline \multicolumn{4}{|l|}{ Negligible } \\
\hline \multicolumn{4}{|l|}{ Highly Unlikely } \\
\hline \multicolumn{4}{|l|}{ Remotely Possible } \\
\hline \multicolumn{4}{|l|}{ Possible } \\
\hline \multicolumn{4}{|l|}{ Somewhat Likely } \\
\hline Likely & $80 \%$ & & \\
\hline Probable & $20 \%$ & & \\
\hline \multicolumn{4}{|l|}{ Highly Probable } \\
\hline Remarkably Probable & & $100 \%$ & $100 \%$ \\
\hline
\end{tabular}

Table 6. Expected losses as a percentage of annual turnover for CLIRMI mine (per incident).

\begin{tabular}{|c|c|c|c|c|c|c|}
\hline \multirow{2}{*}{$\begin{array}{c}\text { Verbal } \\
\text { Expression }\end{array}$} & \multicolumn{2}{|c|}{ Flooding } & \multicolumn{2}{|c|}{ Extreme Winds } & \multicolumn{2}{|c|}{ Heat Waves } \\
\hline & Extraction & Transportation & Extraction & Transportation & Extraction & Transportation \\
\hline \multicolumn{7}{|l|}{ No Effect } \\
\hline \multicolumn{7}{|l|}{ Negligible } \\
\hline Measurable & & & & & $100 \%$ & $100 \%$ \\
\hline Minor & & & & $90 \%$ & & \\
\hline Moderate & & $80 \%$ & & $10 \%$ & & \\
\hline Major & $95 \%$ & $20 \%$ & & & & \\
\hline Serious & $5 \%$ & & & & & \\
\hline \multicolumn{7}{|l|}{ Significant } \\
\hline \multicolumn{7}{|l|}{ Hazardous } \\
\hline Devastating & & & & & & \\
\hline
\end{tabular}


Table 7. Expected economic losses for CLIRMI mine (per incident).

\begin{tabular}{cccc}
\hline \multirow{2}{*}{ Severity of Hazard to Mining Subsystem } & \multicolumn{3}{c}{ Expected Loss (in 1000 euros) } \\
\cline { 2 - 4 } & Min & Mode & Max \\
\hline Flooding impacts to extraction & 80 & 100 & 150 \\
\hline Flooding impacts to transportation & 40 & 50 & 80 \\
\hline Extreme winds impacts to extraction & & No impact & 27 \\
\hline Extreme winds impacts to transportation & 21 & 0.5 & 0.6 \\
\hline Heat waves impacts to extraction & 0.4 & 0.5 & 0.6 \\
\hline Heat waves impacts to transportation & 0.4 & &
\end{tabular}

The results of the discrete BBN (Figure 3), which are presented in Table 8, show that there is a $58 \%$ chance for $2-4 \%$ annual revenue losses, a $41 \%$ chance for $4-5 \%$ annual revenue loss, and a remaining $1 \%$ chance for even more hazardous losses (i.e., between $5-10 \%$ of annual revenues). Given the above-estimated probabilities and the annual turnover of the mine (i.e., $€ 5$ million), the annual losses range from $€ 142,500$ to $€ 223,500$.

Using the CLGN model, the economic losses are estimated, in a more straightforward, i.e., quantitative, way. In this case, the severity nodes are continuous functions following the triangular distributions of Table 7. Figure 4 illustrates the overall CLGN model and presents the distribution of the total economic losses as well as those of the "ore extraction risk" and "transportation risk" nodes. Based on experts' assumptions, the mean annual loss calculated by the CLGN model is about $€ 178,000$ (standard deviation $\approx € 22,000$ ).

In order to illustrate how the CLIRMI framework could assist mine operators in climate adaptation decision-making processes, it is assumed that CLIRMI mine managers examine two distinct adaptation options: (a) mine site drainage to reduce flood risks and (b) loading facilities strengthening to reduce the impact of extreme winds to transportation. Mine site drainage adaptation works comprise of a procurement of a new drainage pump and the construction of several kilometers of levees banks that are capable of prevent flooding events even under extreme rainfall of $200 \mathrm{~mm}$ per day. The implementation of these adaptation works would eliminate the occurrence of flooding events from 14 to less than two in the next 30 years (i.e., the annual likelihood probability decreases from 0.46 to 0.06 ). The total cost of these works is $€ 500,000$. The loading facilities strengthening option has an investment cost of $€ 1.5 \mathrm{~m}$ and consists of upgrading the existing port facilities in order to maintain safe berth status during wind gust speeds of $12 \mathrm{~m} / \mathrm{s}$. As a result, the loading disturbances would be reduced from seven per year to four per decade (i.e., the new annual likelihood for the anticipated hazard becomes 0.4 ). The new annual probabilities for the hazards under consideration are presented in Table 9, and the results for the discrete and the hybrid models, with and without the adaptation measures are given in Tables 8 and 10 , respectively. 


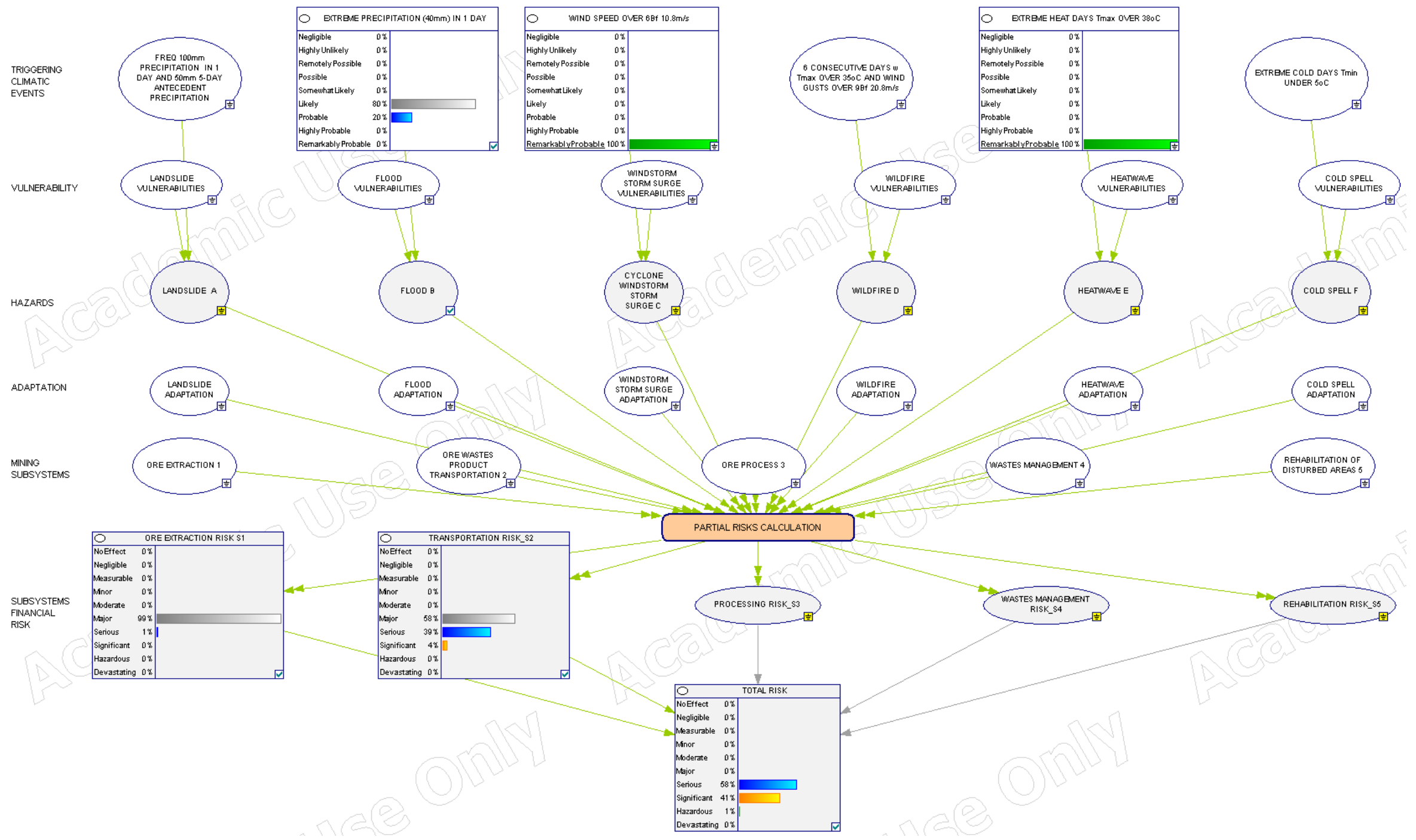

Figure 3. Discrete Bayesian Model for CLIRMI mine main part. 


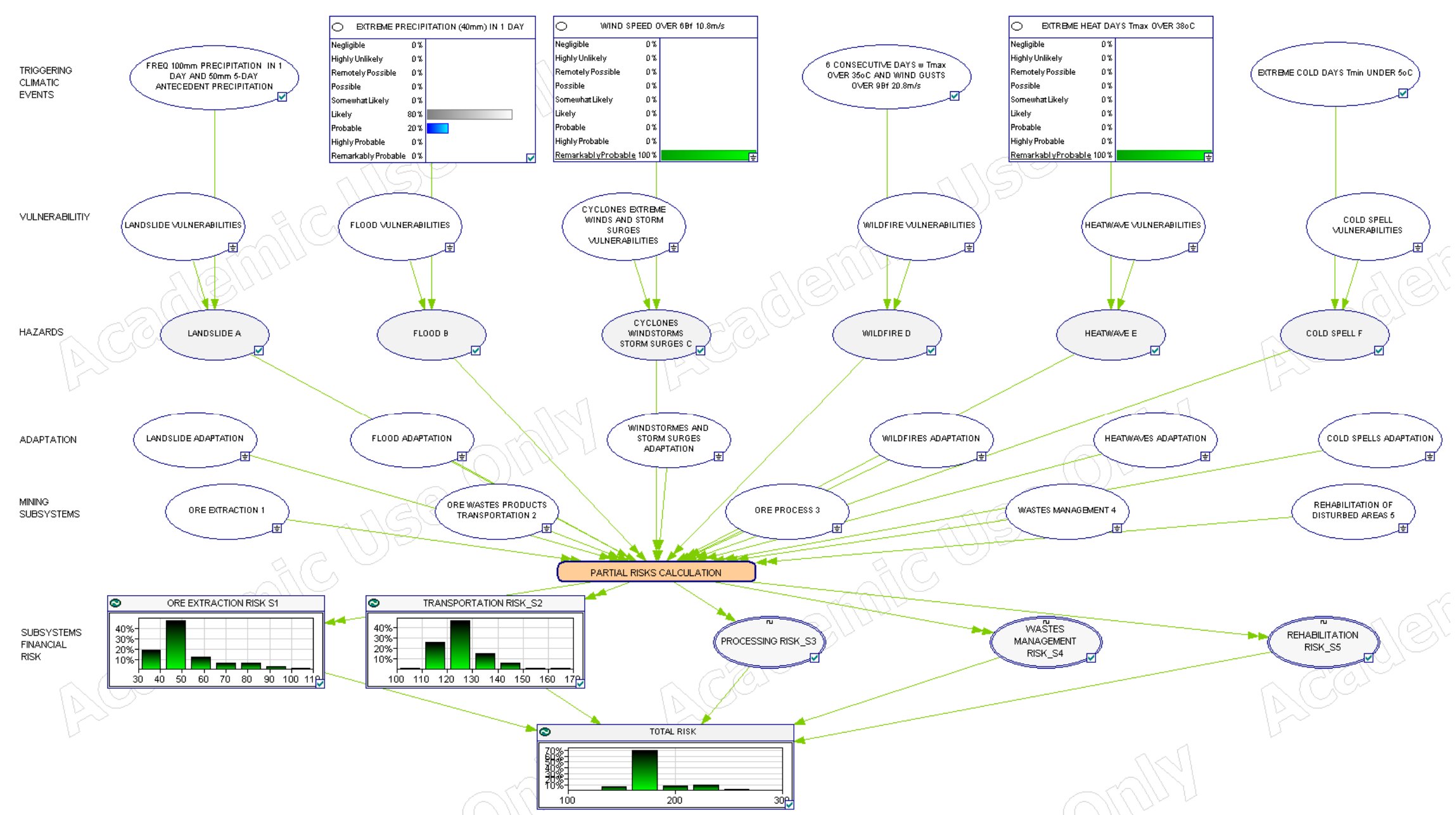

Figure 4. Conditional Linear Gaussian Model for CLIRMI mine main part. 
Table 8. Results of the discrete BBN for CLIRMI mine (economic losses in percentage of annual turnover).

\begin{tabular}{lccc}
\hline Verbal Expression & Without Adaptation & Mine Site Drainage & Port Facilities Strengthening \\
\hline No Effect & & \\
\hline Negligible & & \\
\hline Measurable & & \\
\hline Minor & & & \\
\hline Moderate & & & \\
\hline Major & $58 \%$ & $95 \%$ \\
\hline Serious & $5 \%$ & $5 \%$ \\
\hline Significant & $41 \%$ & & \\
\hline Hazardous & $1 \%$ & & \\
\hline Devastating & & & \\
\hline
\end{tabular}

Table 9. Expected annual likelihood for anticipated hazards for CLIRMI mine with adaptation actions.

\begin{tabular}{|c|c|c|c|}
\hline \multirow{2}{*}{ Qualitative Expression } & \multicolumn{3}{|c|}{ Likelihood Probability for Each Hazard } \\
\hline & Flooding & Extreme Winds & Heat Waves \\
\hline \multicolumn{4}{|l|}{ Negligible } \\
\hline \multicolumn{4}{|l|}{ Highly Unlikely } \\
\hline Remotely Possible & $80 \%$ & & \\
\hline Possible & $20 \%$ & & \\
\hline \multicolumn{4}{|l|}{ Somewhat Likely } \\
\hline \multicolumn{4}{|l|}{ Likely } \\
\hline Probable & & $100 \%$ & \\
\hline \multicolumn{4}{|l|}{ Highly Probable } \\
\hline Remarkably Probable & & & $100 \%$ \\
\hline
\end{tabular}

Table 10. Results of the hybrid CLGN model for CLIRMI mine (economic losses in 1000 euros).

\begin{tabular}{lccc}
\hline Annual Economic Losses & Without Adaptation & Mine Site Drainage & Port Facilities Strengthening \\
\hline Mean & 178 & 111 & 90 \\
\hline Standard deviation & 22 & 6 & 21 \\
\hline
\end{tabular}

The annual adaptation benefits from the mine site drainage and from the improvement of port facilities are equal to $€ 67,000$ and $€ 88,000$, respectively. The equivalent annual cost (EAC) for the adaptation actions, assuming a cost of capital equal to $10 \%$ and a lifespan of 30 years, is estimated to $€ 53,000$ for the mine site drainage and to $€ 159,000$ for the port facilities, using the following equation:

$$
E A C=\frac{r * I}{1-(1+r)^{-n}}
$$

where: $r$ is the cost of capital, $n$ is the lifespan (i.e., 30 years), and $I$ is the investment cost of the adaptation action

In the case of flood risks, the annual benefits (i.e., the reduction in economic losses achieved through adaptation) exceed the annual costs of adaptation and, thus, the adaptation investment is annual savings. On the contrary, the investment in the strengthening of port facilities is not justified, since the annual adaptation cost is higher than the benefits gained by the proposed adaptation action. 


\section{Conclusions}

For several decades, the scientific community made significant progress in various directions of climate change vulnerability analysis, creating alarm about the necessity of climate change mitigation and the incorporation of adaptation strategies in daily operations. Several institutional stakeholders have noted the need to transcend from the vague and obscure vulnerability assessments to a more practical, manageable, and understandable framework for climate change risk assessments such as the one introduced here [42,130-133].

In the present paper, a new framework for the multi-risk assessment of acute climate change-related hazards that occur in the mining sector is introduced. The proposed framework, contrary to other scientific efforts, includes all the relevant extreme events that affect the mining industry permitting the assessment of multiple risks, compounding, and cascading events [44], using a probabilistic model. Our framework follows a bottom-up, vulnerability-based approach [130], based on local knowledge and the expertise of a multi-disciplinary team of experts. As noted by Smit and Wandel [134], this type of participatory vulnerability approach, which induces stakeholders' participation and involvement in all stages, identifies feasible and practical adaptation strategies. Moreover, this type of assessment is perfectly suitable for examining cases with a paucity of data either climatic or corporate.

The model has open-architecture; it is modular, scalable, and can be adjusted to the user needs (i.e., it can be more analytic if the company can provide more detailed data). The proposed risk assessment framework is based on risk analysis, which is a practice that is quite familiar for most mining managers and practitioners, as it is a well-established method in their everyday routine. The main advantage of the model is that it quantifies climate change risks posed to the mining industry in monetary terms through two alternative ways: either as a percentage of annual revenues or as net value. Hence, one of the most useful aspects of the model is the intuitive way of expressing risk in an easily communicable format. In this way, it is our hope that the model can be seen as a useful tool for the mining sector's managers and practitioners for everyday decision making. Nevertheless, it is noted that the proposed framework has also certain limitations. The model is based on expert judgment for the quantification of adverse climate change consequences, which means that: (a) it is prone to cognitive and motivational biases that can occur when eliciting inputs from experts, and (b) the selection of suitable members for the team of experts is extremely crucial for the obtained results. Furthermore, the model does not take into consideration slow onset events such as, for example, sea level rise or permafrost thaw. In some cases, the cost of slow onset events may prove to be high; therefore, future research efforts should shed light on this aspect as well. Further research is needed to fill the gap resulting from the scarcity of past climate change-related costs in the mining sector. Moreover, the proposed model, although originally developed for mining infrastructure, could relatively easily be adapted to other infrastructures in energy, road, railway, etc. Finally, a future improvement of the model is the development of a web-based decision support system. This could help disseminate, use, test, and validate the proposed methodology and facilitate climate-related decision making processes in the mining sector and elsewhere.

Author Contributions: Conceptualization, E.M. and D.D.; methodology, E.M., D.D. and S.M.; model development, E.M.; climatic data, S.M.; writing—original draft preparation, E.M.; writing-review and editing, D.D. and S.M.

Funding: This research received no external funding.

Acknowledgments: The authors wish to thank the three anonymous reviewers for their valuable comments and suggestions on the original manuscript.

Conflicts of Interest: The authors declare no conflict of interest. 


\section{References}

1. IPCC. Climate Change 2013: The Physical Science Basis. Contribution of Working Group I to the Fifth Assessment Report of the Intergovernmental Panel on Climate Change; Stocker, T.F., Qin, D., Plattner, G.K., Tignor, M., Allen, S.K., Boschung, J., Nauels, A., Xia, Y., Bex, V., Midgley, P.M., Eds.; Cambridge University Press: Cambridge, UK, 2013.

2. Kent, A.; Johnson, B. Risk Based Evaluation of Mine Waste Dumps; The Technical and Research Committee on Reclamation: Port Hardy, BC, Canada, 1993; p. 11.

3. Stratos Inc. Climate Change and Acid Rock Drainage_Risks for the Canadian Mining Sector; Mining Association of Canada: Ottawa, ON, Canada, 2011.

4. Yumul, G.P.; Cruz, N.A.; Servando, N.T.; Dimalanta, C.B. Extreme weather events and related disasters in the Philippines, 2004-08: a sign of what climate change will mean? Disasters 2011, 35, 362-382. [CrossRef] [PubMed]

5. Damigos, D. Monetizing the impacts of climate change on the Greek mining sector. Mitig. Adapt. Strateg. Glob. Chang. 2012, 17, 865-878. [CrossRef]

6. Journeaux Associates. Engineering Challenges for Tailings Management Facilities and Associated Infrastructure with Regards to Climate Change in Nunavut; Technical Report no. L-11-1472; Journeaux Associates: Pointe-Claire, QC, Canada, 2012; p. 110.

7. Mason, L.; Giurco, D. Climate Change Adaptation for Australian Minerals Industry Professionals; National Climate Change Adaptation Research Facility: Gold Coast, Australia, 2013; ISBN 978-1-925039-25-2.

8. Mason, L.; Unger, C.; Lederwasch, A.; Razian, H.; Wynne, L.; Giurco, D. Adapting to Climate Risks and Extreme Weather: A Guide for Mining and Minerals Industry Professionals; National Climate Change Adaptation Research Facility: Southport, Australia, 2013; ISBN 978-1-925039-24-5.

9. Sharma, V.; Franks, D.M. In Situ Adaptation to Climatic Change: Mineral Industry Responses to Extreme Flooding Events in Queensland, Australia. Soc. Nat. Resour. 2013, 26, 1252-1267. [CrossRef]

10. Sharma, V.; van de Graaff, S.; Loechel, B.; Franks, D. Extractive Resource Development in a Changing Climate: Learning the Lessons from Extreme Weather Events in Queensland, Australia; National Climate Change Adaptation Research Facility: Gold Coast, Australia, 2013; p. 110.

11. Duerden, F.; Pearce, T.; Ford, J.; Pittman, J. Case Studies of Adaptation to Climate Change in the Yukon Mining Sector: From Planning and Operation to Remediation and Restoration; Natural Resources Canada: Ottawa, ON, Canada, 2014.

12. IPCC. Climate Change 2014: Impacts, Adaptation, and Vulnerability; Field, C.B., Barros, V., Dokken, D., Mach, K.J., Mastrandrea, M.D., Bilir, E., Chatterjee, M., Ebi, K., Estrada, O.Y., Genova, R., et al., Eds.; Cambridge University Press: Cambridge, UK, 2014; ISBN 978-1-107-64165-5.

13. Prior, E.; Wilkins, C.; Jansen, H.R.; Sainsbury, C.; Hill, J.H.; Seleznev, M.; Urquia, R.P. Global Mining: Physical Impacts of Climate Change on 12 Major Mines; Citigroup: Sydney, Australia, 2007; p. 24.

14. International Council on Mining \& Metals ICMM. Adapting to a changing climate: implications for the mining and metals industry. In Climate Change; International Council on Mining \& Metals ICMM: London, UK, 2013; p. 62.

15. International Council on Mining \& Metals ICMM. The Role of Mining in National Economies, 2nd ed.; International Council on Mining \& Metals ICMM: London, UK, 2014; p. 20.

16. Pearce, T.; Ford, J.D.; Prno, J.; Duerden, F. Climate Change and Canadian Mining: Opportunities for Adaptation; David Suzuki Foundation: Vancouver, BC, Canada, 2009; p. 160.

17. Ford, J.D.; Pearce, T.; Prno, J.; Duerden, F.; Ford, L.B.; Beaumier, M.; Smith, T. Perceptions of climate change risks in primary resource use industries: A survey of the Canadian mining sector. Reg. Environ. Chang. 2010, 10, 65-81. [CrossRef]

18. Pearce, T.D.; Ford, J.D.; Prno, J.; Duerden, F.; Pittman, J.; Beaumier, M.; Berrang-Ford, L.; Smit, B. Climate change and mining in Canada. Mitig. Adapt. Strateg. Glob. Chang. 2011, 16, 347-368. [CrossRef]

19. Nelson, J.; Schuchard, R. Adapting to Climate Change: A Guide for the Mining Industry; BSR: New York, NY, USA, 2011; p. 10.

20. Bjelkevik, A. Water Cover Closure Design for Tailings Dams, State of the Art Report; Luleå University of Technology, Department of Civil and Environmental Engineering, Division of Geotechnology: Luleå, Sweden, 2005; p. 103. 
21. Smith, M. Assessing Climate Change Risks and Opportunities for Investors. Mining and Minerals Processing Sector; Australian National University (ANU): Canberra, Australia; Investor Group on Climate Change (IGCC): Sydney, Australia, 2013; p. 22.

22. Becker, A.; Inoue, S.; Fischer, M.; Schwegler, B. Climate change impacts on international seaports: knowledge, perceptions, and planning efforts among port administrators. Clim. Chang. 2011, 110, 5-29. [CrossRef]

23. Sarwar, M.G.M. Impacts of Climate Change on Maritime Industries; World Maritime University: Malmö, Sweden, 2006.

24. Kontogianni, A.; Damigos, D.; Kyrtzoglou, T.; Tourkolias, C.; Skourtos, M. Development of a composite climate change vulnerability index for small craft harbours. Environ. Hazards 2018, 18, 173-190. [CrossRef]

25. Rüttinger, L.; Sharma, V. Climate Change and Mining: A Foreign Policy Perspective; Adelphi: Berlin, Germany, 2016.

26. Prowse, T.D.; Furgal, C.; Chouinard, R.; Melling, H.; Milburn, D.; Smith, S.L. Implications of climate change for economic development in northern Canada: Energy, resource, and transportation sectors. AMBIO 2009, 38, 272-281. [CrossRef]

27. Rosen, J. Cold truths at the top of the world. Nat. News 2016, 532, 296. [CrossRef]

28. Acclimatise Carbon Disclosure Project Report Global Mining Building Business Resilience to Inevitable Climate Change the Adaptation Challenge; Carbon Disclosure Project; Global Mining: Oxford, UK, 2008.

29. ICF Marbek. Adaptation Platform Mining Working Group-State of Play Report. Available online: https://buyandsell.gc.ca/procurement-data/tender-notice/PW-16-00734910 (accessed on 15 June 2019).

30. Grossman, D. Physical Risks from Climate Change: A Guide for Companies and Investors on Disclosure and Management of Climate Impacts; Oxfam America: Boston, MA, USA, 2012.

31. Odell, S.D.; Bebbington, A.; Frey, K.E. Mining and climate change: A review and framework for analysis. Extr. Ind. Soc. 2018, 5, 201-214. [CrossRef]

32. Hodgkinson, J.H.; Hobday, A.J.; Pinkard, E.A. Climate adaptation in Australia's resource-extraction industries: Ready or not? Reg. Environ. Chang. 2014, 14, 1663-1678. [CrossRef]

33. Eckstein, D.; Hutfils, M.-L.; Winges, M. Global Climate Risk Index 2019. Who Suffers Most from Extreme Weather Events? Weather-Related Loss Events in 2017 and 1998 to 2017; German Watch: Bonn, Germany, 2018.

34. Rodgers, C.; Eng, S.; Douglas, A.; Sparling, E.; Byer, P.; Auld, H. Assessing the Treatment of Climate Change Impacts and Adaptation in Project-Level EAs in the Canadian Mining Sector; Ontario Centre for Climate Impacts and Adaptations Resources (OCCIAR) and Risk Sciences International (RSI): Sudbury/Ottawa, ON, Canada, $2014 ;$ p. 86.

35. Landis, W.G.; Durda, J.L.; Brooks, M.L.; Chapman, P.M.; Menzie, C.A.; Stahl, R.G.; Stauber, J.L. Ecological risk assessment in the context of global climate change. Environ. Toxicol. Chem. 2013, 32, 79-92. [CrossRef] [PubMed]

36. Lemmen, D.S.; Warren, F.J.; Lacroix, J.; Bush, E. (Eds.) From Impacts to adaptation:Canada in a Changing Climate 2007; Government of Canada: Ottawa, ON, Canada, 2008.

37. Ford, J.D.; Champalle, C.; Tudge, P.; Riedlsperger, R.; Bell, T.; Sparling, E. Evaluating climate change vulnerability assessments: A case study of research focusing on the built environment in northern Canada. Mitig. Adapt. Strateg. Glob. Chang. 2014, 20, 1267-1288. [CrossRef]

38. Hodgkinson, J.; Littleboy, A.; Howden, M.; Moffat, K.; Loechel, B. Climate Adaptation in the Australian Mining and Exploration Industries; CSIRO: Clayton South Vic, Australia, 2010; ISBN 978-1-921605-81-9.

39. Canadian Mining Innovation Council. Environmental Analysis of the Mining Industry in Canada; Hatch: Vancouver, BC, Canada, 2013.

40. Hodgkinson, J.H.; Loechel, B.; Crimp, S. Informing the future of Australian mining through climate change scenarios. In Proceedings of the 20th International Congress on Modelling and Simulation, Adelaide, Australia, 1-6 December 2013.

41. Loechel, B.; Hodgkinson, J.; Moffat, K. Climate change adaptation in Australian mining communities: comparing mining company and local government views and activities. Clim. Chang. 2013, 119, 465-477. [CrossRef]

42. Warren, F.J.; Lemmen, D.S. (Eds.) Canada in a Changing Climate: Sector Perspectives on Impacts and Adaptation; Government of Canada: Ottawa, ON, Canada, 2014; ISBN 978-1-100-24142-5.

43. World Gold Council. Gold and Climate Change: An Introduction; World Gold Council: London, UK, 2018. 
44. Canadian Standards Association. Mainstreaming the Risk-Based Management of Climate Change Impacts in Canada: Which Guidance Is Needed? Canadian Standards Association: Ontario, ON, Canada, 2010; p. 118.

45. Sustainable Business Institute (SBI); United Nations Environment Programme Finance Initiative. Advancing Adaptation through Climate Information Services; United Nations Environment Programme Finance Initiative: Geneva, Switzerland, 2011.

46. Gallina, V.; Torresan, S.; Critto, A.; Sperotto, A.; Glade, T.; Marcomini, A. A review of multi-risk methodologies for natural hazards: Consequences and challenges for a climate change impact assessment. J. Environ. Manag. 2016, 168, 123-132. [CrossRef] [PubMed]

47. Joint Australian New Zealand Standard ISO 31000:2009 Risk Management Principles and Guidelines; Standards Australia, Sydney and Standards New Zealand: Wellington, New Zealand, 2009.

48. European Commission Risk Assessment and Mapping Guidelines for Disaster Management; Publications Office: Luxembourg, 2010.

49. Gormley, A.; Pollard, S.; Rocks, S.; Black, E. Guidelines for Environmental Risk Assessment and Management UK Climate Change Risk Assessment 2017; Collaborative Centre of Excellence in Understanding and Managing Natural and Environmental Risks, Cranfeld University and Department for Environment, Food and Rural Affairs: Bedfordshire/London, UK, 2011.

50. Garcia-Aristizabal, A.; Gasparini, P.; Uhinga, G. Multi-risk Assessment as a Tool for Decision-Making. In Urban Vulnerability and Climate change in Africa: A Multidisciplinary Approach; Springer International Publishing: Berlin/Heidelberg, Germany, 2015; pp. 229-258.

51. Guideline on Climate Change Adaptation and Risk Assessment in the Danube Macro-Region. Available online: http://www.rsoe.hu/projectfiles/seeriskOther/download/climate_change_adaptation.pdf (accessed on 15 June 2019).

52. Papathoma-Köhle, M.; Promper, C.; Glade, T. A Common Methodology for Risk Assessment and Mapping of Climate Change Related Hazards-Implications for Climate Change Adaptation Policies. Climate 2016, 4, 8. [CrossRef]

53. Olfert, A.; Greiving, S.; Batista, M.J. Regional Multi-Risk Review, Hazard Weighting Spatial Planning Response to Risk-Results from European Case Studies; Geological Survey of Finland: Espoo, Finland, 2006.

54. Greiving, S. Integrated risk assessment of multi-hazards: A new methodology. Spec. Pap.-Geol. Surv. Finl. 2006, 42, 75 .

55. Schmidt-Thomé, P. The spatial effects and management of natural and technological hazards in Europe. Final Rep. Eur. Spat. Plan. Obs. Netw. (ESPON) Proj. 2006, 1, 1-197.

56. Metzger, M.J.; Leemans, R.; Schröter, D. A multidisciplinary multi-scale framework for assessing vulnerabilities to global change. Int. J. Appl. Earth Obs. Geoinf. 2005, 7, 253-267. [CrossRef]

57. Metzger, M.J.; Rounsevell, M.D.A.; Acosta-Michlik, L.; Leemans, R.; Schröter, D. The vulnerability of ecosystem services to land use change. Agric. Ecosyst. Environ. 2006, 114, 69-85. [CrossRef]

58. Rayne, S.; Forest, K.; Friesen, K.J. Analytical Framework for a Risk-based Estimation of Climate Change Effects on Mine Site Runoff Water Quality. Mine Water Environ. 2009, 28, 124-135. [CrossRef]

59. Chen, Y.; Liu, R.; Barrett, D.; Gao, L.; Zhou, M.; Renzullo, L.; Emelyanova, I. A spatial assessment framework for evaluating flood risk under extreme climates. Sci. Total Environ. 2015, 538, 512-523. [CrossRef] [PubMed]

60. Liu, R.; Chen, Y.; Wu, J.; Gao, L.; Barrett, D.; Xu, T.; Li, L.; Huang, C.; Yu, J. Assessing spatial likelihood of flooding hazard using naïve Bayes and GIS: a case study in Bowen Basin, Australia. Stoch. Environ. Res. Risk Assess. 2016, 30, 1575-1590. [CrossRef]

61. Tsavdaroglou, M.; Al-Jibouri, S.H.S.; Bles, T.; Halman, J.I.M. Proposed methodology for risk analysis of interdependent critical infrastructures to extreme weather events. Int. J. Crit. Infrastruct. Prot. 2018, 21, 57-71. [CrossRef]

62. Bles, T.; Ennesser, Y.; Falemo, S.; Lind, B.; Mens, M.; Ray, M.; Sandersen, F. Risk Management for Roads in a Changing Climate. Available online: https://rimis.ec.europa.eu/project/risk-management-roads-changingclimate (accessed on 15 June 2019).

63. Engineers Canada. PIEVC Enginnering Protocol for Infrastructure Vulnerability Assessment and Adaptation to a Changing Climate; Canadian Council of Professional Engineers: Ottawa, ON, Canada, 2011.

64. McConnach, J.S.; Zobaa, A.F.; Lapp, D. Impacts of Climate Change on the Power Industry and How It is Adapting; InTech: London, UK, 2011; ISBN 978-953-307-621-8. 
65. Etkin, D.; Paoli, G.; Riseborough, D. Climate Change Impacts on Permafrost Engineering Design; Environmental Adaptation Research Group, Atmospheric Environment Service, Environment Canada: Toronto, ON, Canada, 1998.

66. Jäger, W.S.; Christie, E.K.; Hanea, A.M.; den Heijer, C.; Spencer, T. A Bayesian network approach for coastal risk analysis and decision making. Coast. Eng. 2018, 134, 48-61. [CrossRef]

67. Zhou, Q.; Mikkelsen, P.S.; Halsnæs, K.; Arnbjerg-Nielsen, K. Framework for economic pluvial flood risk assessment considering climate change effects and adaptation benefits. J. Hydrol. 2012, 414-415, 539-549. [CrossRef]

68. Ogden, A.E.; Innes, J.L. Application of Structured Decision Making to an Assessment of Climate Change Vulnerabilities and Adaptation Options for Sustainable Forest Management. Ecol. Soc. 2009, 14. [CrossRef]

69. Bradley, J.R. An improved method for managing catastrophic supply chain disruptions. Bus. Horiz. 2014, 57, 483-495. [CrossRef]

70. Pearl, J.; Russel, S. Bayesian Networks. In Handbook of Brain Theory and Neural Networks; Arbib, M.A., Ed.; MIT Press: Cambridge, MA, USA, 2003.

71. Zerrouki, H.; Smadi, H. Bayesian Belief Network Used in the Chemical and Process Industry: A Review and Application. J. Fail. Anal. Preven. 2017, 17, 159-165. [CrossRef]

72. Ropero, R.F.; Rumí, R.; Aguilera, P.A. Bayesian networks for evaluating climate change influence in olive crops in Andalusia, Spain. Nat. Resour. Model. 2019, 32, e12169. [CrossRef]

73. Hobbs, B.F. Bayesian Methods for Analysing Climate Change and Water Resource Uncertainties. J. Environ. Manag. 1997, 49, 53-72. [CrossRef]

74. Varis, O.; Kuikka, S. Bene-Eia: A Bayesian Approach to Expert Judgment Elicitation with Case Studies on Climate Change Impacts on Surface Waters. Clim. Chang. 1997, 37, 539-563. [CrossRef]

75. Franco, C.; Hepburn, L.A.; Smith, D.J.; Nimrod, S.; Tucker, A. A Bayesian Belief Network to assess rate of changes in coral reef ecosystems. Environ. Model. Softw. 2016, 80, 132-142. [CrossRef]

76. Bertone, E.; Sahin, O.; Richards, R.; Roiko, R.A. Bayesian Network and system thinking modelling to manage water-related health risks from extreme events. In Proceedings of the 2015 IEEE International Conference on Industrial Engineering and Engineering Management (IEEM), Singapore, 6-9 December 2015; pp. 1272-1276.

77. Pollino, C.A.; Hart, B.T.; Bolton, B.R. Modelling ecological risks from mining activities in a tropical system. Australas. J. Ecotoxicol. 2008, 14, 119.

78. Bashari, H.; Naghipour, A.A.; Khajeddin, S.J.; Sangoony, H.; Tahmasebi, P. Risk of fire occurrence in arid and semi-arid ecosystems of Iran: An investigation using Bayesian belief networks. Environ. Monit. Assess. 2016, 188, 531. [CrossRef] [PubMed]

79. Hough, R.L.; Towers, W.; Aalders, I. The Risk of Peat Erosion from Climate Change: Land Management Combinations-An Assessment with Bayesian Belief Networks. Hum. Ecol. Risk Assess. Int. J. 2010, 16, 962-976. [CrossRef]

80. Li, L.; Wang, J.; Leung, H.; Jiang, C. Assessment of Catastrophic Risk Using Bayesian Network Constructed from Domain Knowledge and Spatial Data. Risk Anal. 2010, 30, 1157-1175. [CrossRef]

81. Webster, K.L.; McLaughlin, J.W. Application of a Bayesian belief network for assessing the vulnerability of permafrost to thaw and implications for greenhouse gas production and climate feedback. Environ. Sci. Policy 2014, 38, 28-44. [CrossRef]

82. Tolo, S.; Patelli, E.; Beer, M. Enhanced Bayesian Network approach to sea wave overtopping hazard quantification. In Proceedings of the 25th European Safety and Reliability Conference (ESREL), Zurich, Switzerland, 7-10 September 2015; pp. 1983-1990.

83. Castelletti, A.; Soncini-Sessa, R. Bayesian Networks and participatory modelling in water resource management. Environ. Model. Softw. 2007, 22, 1075-1088. [CrossRef]

84. Marcot, B.G.; Steventon, J.D.; Sutherland, G.D.; McCann, R.K. Guidelines for developing and updating Bayesian belief networks applied to ecological modeling and conservation. Can. J. For. Res. 2006, 36, 3063-3074. [CrossRef]

85. Uusitalo, L. Advantages and challenges of Bayesian networks in environmental modelling. Ecol. Model. 2007, 203, 312-318. [CrossRef]

86. Landuyt, D.; Broekx, S.; D’hondt, R.; Engelen, G.; Aertsens, J.; Goethals, P.L.M. A review of Bayesian belief networks in ecosystem service modelling. Environ. Model. Softw. 2013, 46,1-11. [CrossRef] 
87. Varis, O.; Kuikka, S. Learning Bayesian decision analysis by doing: lessons from environmental and natural resources management. Ecol. Model. 1999, 119, 177-195. [CrossRef]

88. Catenacci, M.; Giupponi, C. Potentials of Bayesian Networks to Deal with Uncertainty in Climate Change Adaptation Policies. CMCC Res. Pap. 2009. [CrossRef]

89. Sperotto, A.; Molina, J.-L.; Torresan, S.; Critto, A.; Marcomini, A. Reviewing Bayesian Networks potentials for climate change impacts assessment and management: A multi-risk perspective. J. Environ. Manag. 2017, 202, 320-331. [CrossRef] [PubMed]

90. Aguilera, P.A.; Fernández, A.; Fernández, R.; Rumí, R.; Salmerón, A. Bayesian networks in environmental modelling. Environ. Model. Softw. 2011, 26, 1376-1388. [CrossRef]

91. Darling, P. (Ed.) SME Mining Engineering Handbook, 3rd ed.; SME-Soc. for Mining, Metallurgy, and Exploration, Inc.: Englewood, CO, USA, 2011; ISBN 978-0-87335-341-0.

92. Phillips, J. Climate change and surface mining: A review of environment-human interactions \& their spatial dynamics. Appl. Geogr. 2016, 74, 95-108.

93. Hodgkinson, J.H.; Smith, M.H. Climate change and sustainability as drivers for the next mining and metals boom: The need for climate-smart mining and recycling. Resour. Policy 2018, in press.

94. United Nations' Framework Convention on Climate Change UNFCCC Technical Paper on Slow Onset Events. Available online: https://unfccc.int/sites/default/files/resource/docs/2012/tp/07.pdf (accessed on 15 June 2019).

95. Gao, L.; Bryan, B.A.; Liu, J.; Li, W.; Chen, Y.; Liu, R.; Barrett, D. Managing too little and too much water: Robust mine-water management strategies under variable climate and mine conditions. J. Clean. Prod. 2017, 162, 1009-1020. [CrossRef]

96. Huxtable, C. Rehabilitation of Open Cut Coal Mines Using Native Grasses: Management Guidelines; Centre for Natural Resources, Department of Sustainable Natural Resources: Parramatta, Australia, 2003; p. 12.

97. Kong, J.; Pei, Z.; Du, M.; Sun, G.; Zhang, X. Effects of arbuscular mycorrhizal fungi on the drought resistance of the mining area repair plant Sainfoin. Int. J. Min. Sci. Technol. 2014, 24, 485-489. [CrossRef]

98. Sánchez-Salguero, R.; Camarero, J.J.; Hevia, A.; Madrigal-González, J.; Linares, J.C.; Ballesteros-Canovas, J.A.; Sánchez-Miranda, A.; Alfaro-Sánchez, R.; Sangüesa-Barreda, G.; Galván, J.D.; et al. What drives growth of Scots pine in continental Mediterranean climates: Drought, low temperatures or both? Agric. For. Meteorol. 2015, 206, 151-162. [CrossRef]

99. Winkler, N.; Weymann, W.; Auge, H.; Klotz, S.; Finkenbein, P.; Heilmeier, H. Drought resistance of native pioneer species indicates potential suitability for restoration of post-mining areas. Web Ecol. 2015, 14, 65-74. [CrossRef]

100. Onederra, I.; Gonzalez, J.I.L. Environmental Management Initiatives Concerning Energy and Water Challenges in the Chilean Mining Industry; The University of Queensland: Brisbane, Australia, 2018.

101. IMG Golder Corporation. Vulnerability Assessment of the Mining Sector to Climate Change Task 1 Report; Natural Resources' Canada Nunavut Regional Adaptation Collaborative (RAC); Government of Nunavut: Ottawa, ON; Cambridge Bay, NU, Canada, 2012.

102. Luers, A.L.; Lobell, D.B.; Sklar, L.S.; Addams, C.L.; Matson, P.A. A method for quantifying vulnerability, applied to the agricultural system of the Yaqui Valley, Mexico. Glob. Environ. Chang. 2003, 13, 255-267. [CrossRef]

103. Adger, W.N. Vulnerability. Glob. Environ. Chang. 2006, 16, 268-281. [CrossRef]

104. Kasperson, R.E.; Kasperson, J. Social Contours of Risk: Volume II: Risk Analysis, Corporations \& the Globalization of Risk, 1st ed.; Routledge: London, UK, 2005; ISBN 978-1-84407-072-5.

105. Fuchs, S.; Birkmann, J.; Glade, T. Vulnerability assessment in natural hazard and risk analysis: current approaches and future challenges. Nat. Hazards 2012, 64, 1969-1975. [CrossRef]

106. Corominas, J.; van Westen, C.; Frattini, P.; Cascini, L.; Malet, J.-P.; Fotopoulou, S.; Catani, F.; Eeckhaut, M.V.D.; Mavrouli, O.; Agliardi, F.; et al. Recommendations for the quantitative analysis of landslide risk. Bull. Eng. Geol. Environ. 2013, 73, 209-263. [CrossRef]

107. Gaprindashvili, G.; Van Westen, C.J. Generation of a national landslide hazard and risk map for the country of Georgia. Nat. Hazards 2016, 80, 69-101. [CrossRef]

108. Tomczyk, A.M.; White, P.C.L.; Ewertowski, M.W. Effects of extreme natural events on the provision of ecosystem services in a mountain environment: The importance of trail design in delivering system resilience and ecosystem service co-benefits. J. Environ. Manag. 2016, 166, 156-167. [CrossRef] [PubMed] 
109. Zhang, X.; Alexander, L.; Hegerl, G.C.; Jones, P.; Tank, A.K.; Peterson, T.C.; Trewin, B.; Zwiers, F.W. Indices for monitoring changes in extremes based on daily temperature and precipitation data. Wiley Interdiscip. Rev. Clim. Chang. 2011, 2, 851-870. [CrossRef]

110. Bradshaw, C.J.A.; Sodhi, N.S.; Peh, K.S.-H.; Brook, B.W. Global evidence that deforestation amplifies flood risk and severity in the developing world. Glob. Chang. Biol. 2007, 13, 2379-2395. [CrossRef]

111. Burgess, C.P.; Taylor, M.A.; Stephenson, T.; Mandal, A.; Powell, L. A macro-scale flood risk model for Jamaica with impact of climate variability. Nat. Hazards 2015, 78, 231-256. [CrossRef]

112. Kazakis, N.; Kougias, I.; Patsialis, T. Assessment of flood hazard areas at a regional scale using an index-based approach and Analytical Hierarchy Process: Application in Rhodope-Evros region, Greece. Sci. Total Environ. 2015, 538, 555-563. [CrossRef] [PubMed]

113. Grünthal, G.; Thieken, A.H.; Schwarz, J.; Radtke, K.S.; Smolka, A.; Merz, B. Comparative risk assessments for the city of Cologne-storms, floods, earthquakes. Nat. Hazards 2006, 38, 21-44. [CrossRef]

114. Piñol, J.; Terradas, J.; Lloret, F. Climate Warming, Wildfire Hazard, and Wildfire Occurrence in Coastal Eastern Spain. Clim. Chang. 1998, 38, 345-357. [CrossRef]

115. Hennessy, K.J.; Lucas, C.; Nicholls, N.; Bathols, J.; Suppiah, R.; Ricketts, J. Climate Change Impacts on Fire-Weather in South-East Australia; CSIRO Marine and Atmospheric Research: Aspendale, Austrilia, 2005; ISBN 978-1-921061-10-3.

116. Preston, B.L.; Brooke, C.; Measham, T.G.; Smith, T.F.; Gorddard, R. Igniting change in local government: lessons learned from a bushfire vulnerability assessment. Mitig. Adapt. Strateg. Glob. Chang. 2008, 14, 251-283. [CrossRef]

117. Karali, A.; Hatzaki, M.; Giannakopoulos, C.; Roussos, A.; Xanthopoulos, G.; Tenentes, V. Sensitivity and evaluation of current fire risk and future projections due to climate change: the case study of Greece. Nat. Hazards Earth Syst. Sci. 2014, 14, 143-153. [CrossRef]

118. Kambezidis, H.D.; Kalliampakos, G.K. Fire-Risk Assessment in Northern Greece Using a Modified Fosberg Fire-Weather Index That Includes Forest Coverage. Int. J. Atmos. Sci. 2016, 2016. [CrossRef]

119. Diffenbaugh, N.S.; Pal, J.S.; Giorgi, F.; Gao, X. Heat stress intensification in the Mediterranean climate change hotspot. Geophys. Res. Lett. 2007, 34. [CrossRef]

120. Nastos, P.T.; Kapsomenakis, J. Regional climate model simulations of extreme air temperature in Greece. Abnormal or common records in the future climate? Atmos. Res. 2015, 152, 43-60. [CrossRef]

121. BayesFusion LLC. GeNIe Modeler User Manual; BayesFusion LLC: Pittsburgh, PA, USA, 2017.

122. Wilson, K.E.; Adams, P.N.; Hapke, C.J.; Lentz, E.E.; Brenner, O. Application of Bayesian Networks to hindcast barrier island morphodynamics. Coast. Eng. 2015, 102, 30-43. [CrossRef]

123. Kjærulff, U.B.; Madsen, A.L. Bayesian Networks and Influence Diagrams: A Guide to Construction and Analysis. In Information Science and Statistics, 1st ed.; Springer: New York, NY, USA, 2008; ISBN 978-0-387-74100-0.

124. Koller, D.; Friedman, N. Probabilistic Graphical Models: Principles and Techniques; Adaptive Computation and Machine Learning; MIT Press: Cambridge, MA, USA, 2009; ISBN 978-0-262-01319-2.

125. Fenton, N.E.; Neil, M.D. Risk Assessment and Decision Analysis with Bayesian Networks; CRC Press: Boca Raton, FL, USA, 2013; ISBN 978-1-4398-0911-2.

126. BayesFusion LLC Suggestion on "Network Structure too Complex". Available online: https://web.archive. org/web/20190609053012/https://support.bayesfusion.com/forum/viewtopic.php?f=3\&t=4619 (accessed on 19 June 2019).

127. Ford, J.D.; Pearce, T.; Prno, J.; Duerden, F.; Ford, L.B.; Smith, T.R.; Beaumier, M. Canary in a coal mine: Perceptions of climate change risks and response options among Canadian mine operations. Clim. Chang. 2011, 109, 399-415. [CrossRef]

128. Salmerón, A.; Rumí, R.; Langseth, H.; Madsen, A.L.; Nielsen, T.D. MPE Inference in Conditional Linear Gaussian Networks. In Symbolic and Quantitative Approaches to Reasoning with Uncertainty; Destercke, S., Denoeux, T., Eds.; Springer International Publishing: Cham, Switzerland, 2015; Volume 9161, pp. 407-416. ISBN 978-3-319-20806-0.

129. Hwacha, V. Canada's Experience in Developing a National Disaster Mitigation Strategy: A Deliberative Dialogue Approach. Mitig. Adapt. Strateg. Glob. Chang. 2005, 10, 507-523. [CrossRef] 
130. United Nations Framework Convention on Climate Change (UNFCCC). Application of Methods and Tools for Assessing Impacts and Vulnerability, and Developing Adaptation Responses; UNFCCC Secretariat: Rio de Janeiro, Brazil, 2004.

131. Lim, B.; Spanger-Siegfried, E. (Eds.) Adaptation Policy Frameworks for Climate Change: Developing Strategies, Policies and Measures; United Nations Development Programme; Cambridge University Press: Cambridge, UK, 2004.

132. International Council on Mining \& Metals ICMM. Measurement, Reporting and Verification and the Mining and Metals Industry; International Council on Mining \& Metals ICMM: London, UK, 2011.

133. Global Reporting Initiative GRI. Sustainability Reporting Guidelines E Mining and Metals Sector Supplement; Global Reporting Initiative GRI: Amsterdam, The Netherlands, 2011.

134. Smit, B.; Wandel, J. Adaptation, adaptive capacity and vulnerability. Glob. Environ. Chang. 2006, 16, $282-292$. [CrossRef]

(C) 2019 by the authors. Licensee MDPI, Basel, Switzerland. This article is an open access article distributed under the terms and conditions of the Creative Commons Attribution (CC BY) license (http://creativecommons.org/licenses/by/4.0/). 